\title{
Use of Nanomaterials in the Pretreatment of Water Samples for Environmental Analysis
}

\author{
Sandra C. Bernardo, Ana C. A. Sousa, Márcia C. Neves and Mara G. Freire** \\ CICECO - Aveiro Institute of Materials, Chemistry Department, University of Aveiro, 3810-193 Aveiro, \\ Portugal
}

\begin{abstract}
The challenge of providing clean drinking water is of enormous relevance in today's human civilization, being essential for human consumption, but also for agriculture, livestock and several industrial applications. In addition to remediation strategies, the accurate monitoring of pollutants in water supplies, which most of the times are present at low concentrations, is a critical challenge. The usual low concentration of target analytes, the presence of interferents and the incompatibility of the sample matrix with instrumental techniques and detectors are the main reasons that renders sample preparation a relevant part of environmental monitoring strategies. The discovery and application of new nanomaterials allowed improvements on the pretreatment of water samples, with benefits in terms of speed, reliability and sensitivity in analysis. In this chapter, the use of nanomaterials in solid-phase extraction (SPE) protocols for water samples pretreatment for environmental monitoring is addressed. The most used nanomaterials, including metallic nanoparticles, metal organic frameworks, molecularly imprinted polymers, carbon-based nanomaterials, silica-based nanoparticles and nanocomposites are described, and their applications and advantages overviewed. Main gaps are identified and new directions on the field are suggested.
\end{abstract}

\subsection{Introduction}

Since the beginning of industrialization and due to the continuous population growth, anthropogenic activities have been constantly rising, allowing many toxic compounds to reach the aquatic environment (Hussain and Kharisov, 2016). According to the United Nations Environmental Program (UNEP) and the Food and Agriculture Organization of the United Nations (FAO), the contamination of the aquatic environment and consequently water pollution is a global challenge, both in developed and developing countries (UNEP/UNECE, 2016; FAO, 2017; WWAP, 2017). The contamination of the aquatic environment has negative impacts on

1 Mara G. Freire (Corresponding Author)

E-mail address: maragfreire@ua.pt; Tel: +351-234401422; Fax: +351-234370084 
ecosystems and human health and, consequently, undermines economic growth. To address this important problem it is necessary to understand the extension of water contamination, where environmental monitoring is essential. However, some of the compounds that are being accumulated in the environment are sometimes close or under the detection limits of the currently available analytical techniques, despite being toxic at very low concentrations. In order to assess the current levels of these pollutants in the environment it is crucial to modernize and improve the performance of analytical techniques, so that pollutants that are present at ultralow concentrations in environmental samples could be detected and quantified with accuracy and consistency (Scragg, 2005; Hussain and Kharisov, 2016).

Pollutants are occasionally ubiquitous contaminants; most of them can migrate from the point sources and contaminate other areas where they are not used (Scragg, 2005). According to the UNEP (UNEP, no date b), the sources of contamination are diverse and include, for example, agriculture and food (e.g. land based farming, agroindustry, fisheries and aquaculture), energy (e.g. fossil fuels, biomass), industry (e.g. chemical, mining, and petrochemical), manufacturing (e.g. pharmaceuticals, home appliances, electronics), services (e.g. health care, tourism), transports (e.g. fuel use, engine emissions) and waste (e.g. municipal and industrial solid waste, hazardous waste, wastewater effluents, leachates) (Fig. 11.1).

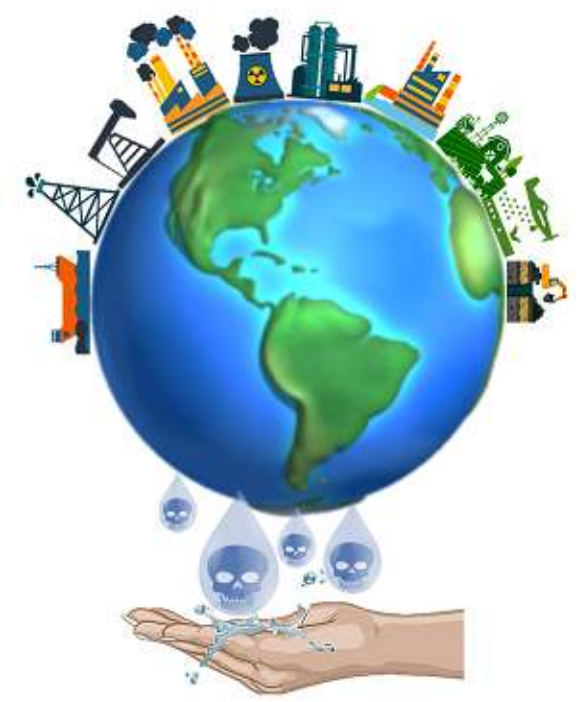

Fig. 11.1. Schematic representation of examples of human activities and pollutant's sources of water contamination.

The most common pollutants found in the environment (water, soil and air) include metals, polycyclic aromatic hydrocarbons (PAHs), persistent organic pollutants (POPs), pesticides, and pharmaceutical drugs (Liang and Guo, 2009; Hussain and Kharisov, 2016).

Metals are naturally occurring elements that due to human activities are being re-introduced in the environment, e.g. from agriculture activities and wastes from industrial processes (Scragg, 2005; UNEP, Working Group on the Global Metal Flows to the International Resource 
Panel. van der Voet, E.; Salminen, R.; Eckelman, M.; Mudd, G.; Norgate, T.; Hischier, 2013). Once released, some metals such as cadmium, lead, copper, chromium, mercury, uranium, nickel, cobalt, zinc, arsenic, selenium, thallium, and antimony, tend to bioaccumulate (Akpor, 2014). Some of these metals, such as mercury, are also able to bioconcentrate along the food chain and they can even cross the blood brain barrier, being considered as extremely toxic (Bjørklund et al., 2017). These pollutants have been extensively studied since water contamination with metals poses serious health risks due to their high toxicity (most are carcinogenic and teratogenic substances) (Scragg, 2005; Vunain, Mishra and Mamba, 2016; Carolin et al., 2017). Hence, these toxic metals have been prioritized as the major inorganic contaminants in the environment; furthermore, they are non-biodegradable, highly persistent and present high mobility between ecosystems (Vunain, Mishra and Mamba, 2016).

Polycyclic aromatic hydrocarbons (PAHs) are hydrocarbons with two or more fused aromatic rings. PAHs are produced from the incomplete combustion or pyrolysis of carbonaceous and organic matter (coal, diesel, gas, wood, etc.). Their major anthropogenic sources into the atmosphere and environment include industrial processes, vehicle exhausts, energy producing plants, waste incineration, and domestic heating emissions (Pandey, Kim and Brown, 2011; Sajid et al., 2018). PAHs are highly toxic and some of them are mutagenic and carcinogenic (Scragg, 2005; Sajid et al., 2018). PAHs are ubiquitous in the environment being detected in all compartments (air, soils and water). In what concerns aquatic systems, PAHs have been detected in river, lakes, oceans and also in groundwater and drinking water (Menzie, Potocki and Santodonato, 1992; Burgess, Ahrens and Hickey, 2003)).

Persistent organic pollutants (POPs) are a group of manmade chemicals that are persistent, toxic and globally distributed. These chemicals are even found at high levels in regions where they were not used, including the Arctic. POPs include different classes of chemicals, as for example, polychlorinated biphenyls (PCBs), dioxins and furans, organochlorine pesticides (e.g. dichlorodiphenyl trichloroethane (DDT), polybrominated diphenyl ethers (PBDEs), shortchained chlorinated paraffins or perfluorooctane sulfonic acids (PFOS)). Their deleterious effects include cancer, neurotoxicity, immunotoxicity and endocrine disruption. They are regulated under the Stockholm convention and their use is mostly banned (UNEP, no date a).

Another commonly found type of pollutants, especially due to agriculture activities, are pesticides, which include herbicides, fungicides and insecticides (UNEP, no date c). Pesticides are a wide-ranging group of chemical compounds, including organochlorines, organophosphates, carbamates, chloroacetanilide, pyrethroids and neonicotinoids (Kaur et al., 2014; Wang et al., 2017). They are widely used to prevent crops destruction by any plague and to increase the agriculture productivity, leading to their accumulation in the food chain and in the contamination of air, water and soil (Kaur et al., 2014; Wang et al., 2017).

Despite the important role of pharmaceuticals for assuring public health safety, their excessive and prolonged use poses serious environmental concerns. Pharmaceuticals are not completely metabolized by the human body, being mainly discharged by urine and reaching wastewater treatment plants (WWTPs) (Lolic et al., 2015). Furthermore, daily tons of these compounds are directly loaded in the sewage systems. However, most of the pharmaceutical drugs and their bioactive metabolites are not completely removed since WWTPs are mainly designed to remove suspended solids and organic loadings, leading to a continuous discharge of these compounds into the environment (Lolic et al., 2015). Antibiotics, for instance, are amongst the pharmaceutical drugs presenting a higher threat; they induce toxic effects at very 
low concentrations and can in a long-term contribute to the growth of antibiotic-resistant bacteria (Wang et al., 2018). But other drugs are also of high concern due to their large consumption and release into the environment, such as non-steroidal anti-inflammatory drugs (NSAIDs), analgesics, $\beta$-blockers, lipid regulators and psychiatric drugs. The European Union established regulatory guidance to assess the presence of pharmaceuticals in the aquatic environment, in which several drugs are included in the watch list, namely the hormones 17-alphaethinylestradiol and 17-beta-estradiol, and the NSAID diclofenac, as they may pose a significant risk to the aquatic environment and for which monitoring data are insufficient (European Commission, 2013; Lolic et al., 2015).

Due to the serious concern associated to these pollutants, the European union implemented the Water Framework Directive (WFD) (European Commission, 2013), requiring their determination down to the ng. $\mathrm{L}^{-1}$ range (Liang and Guo, 2009). Accordingly, the improvement of the sensitivity of analytical techniques currently used to identify and quantify the several pollutants present in aqueous samples is in high demand (Liang and Guo, 2009; Hussain and Kharisov, 2016). However, the key difficulty in environmental analysis is connected to the low sensitivity and selectivity of the used analytical techniques. Most of the times these are insufficient for determining the low concentration levels and to eliminate interferences arising from the complex environmental matrices, turning mandatory a sample treatment step prior to analysis (Liang and Guo, 2009). However, sample pretreatment is still one of the most time- and labor-consuming parts in environmental analysis, and has been subject of intensive research over the past 20 years (Hussain and Kharisov, 2016).

\subsection{Improvement of Environmental Analysis using Nanomaterials}

Environmental analysis can be defined as the use of analytical chemistry techniques to detect and quantify pollutants in the environment (Nilsson, Birnbaum and Nilsson, 2007). The high demand for environmental monitoring is confirmed by the increasing number of reports along the years, as shown in Fig. 11.2. Around 2001, a boom of publications on this matter arouse, especially due to the introduction of nanomaterials in environmental monitoring. Accordingly, more than $10 \%$ of the total of publications concerning the analysis of environmental samples are related with the use of nanomaterials, as summarized in Fig. 11.3. From these publications it is possible to ascertain the types of samples used, namely "water", "soil" and "air", being the water samples those that correspond to a higher number of publications (34\%). Moreover, $11.5 \%$ of the total publications comprise the use of "nanomaterials" for the analysis of environmental samples (Fig. 11.3). 


\section{ENVIRONMENTAL MONITORING}

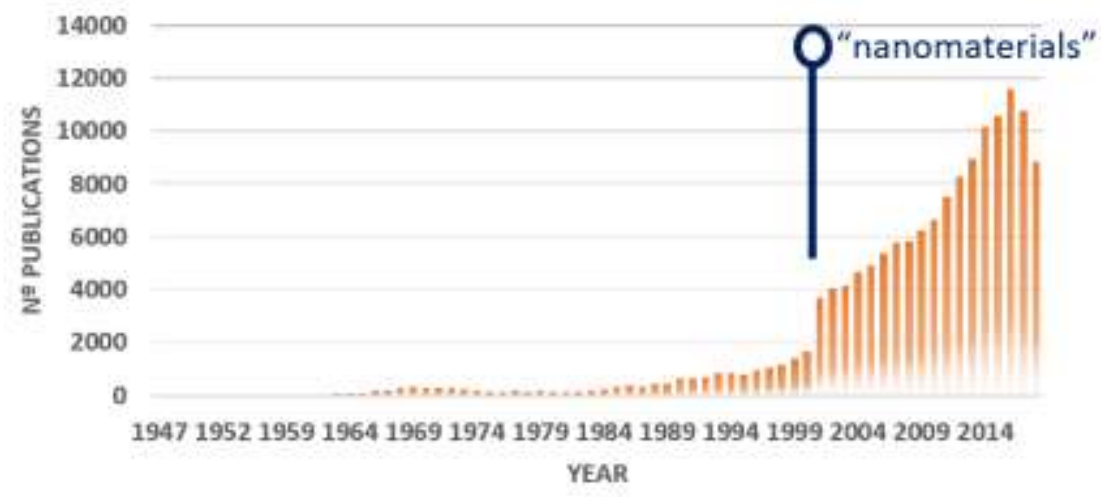

Fig. 11.2. Number of publications per year (from 1947 to 2018) focusing on environmental monitoring. The search was carried out in the PUBMED database in December 2018 using the keywords "environmental monitoring". The search was refined using the additional keyword "nanomaterials". Publications dealing with nanomaterials in environmental monitoring appeared after 2001.

\section{analysis environmental samples}

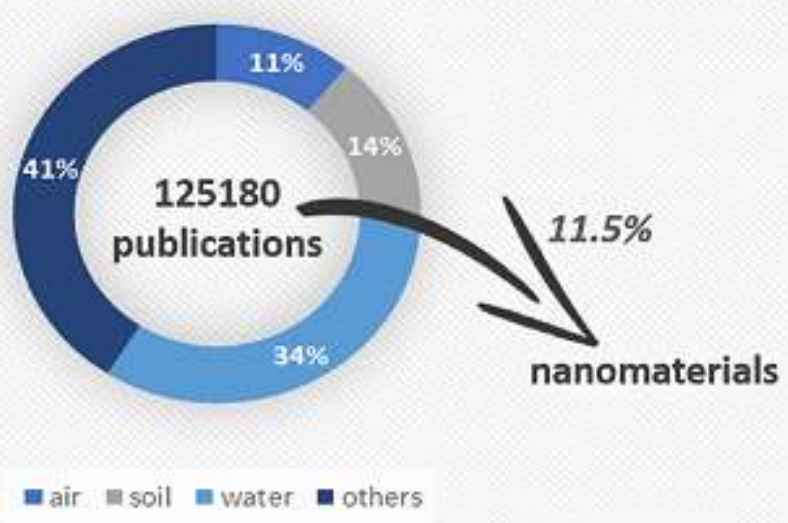

Fig. 11.3. Overview on publications (from 1947 to 2018) focusing on the analysis of environmental samples. The search was carried out in the PUBMED database using the keywords "analysis", "environmental" and "samples",

Nanomaterials could have different applications in environmental analysis. For instance, they can be used as sorbent materials in solid-phase extraction (SPE) for sample pretreatment 
prior to the analysis (Savage and Diallo, 2005; Liang and Guo, 2009), as supports for the fabrication of sensors (Liang and Guo, 2009), or as stationary or pseudostationary phases in several analytical techniques (Zhang et al., 2006; Liang and Guo, 2009) (Fig. 11.4).

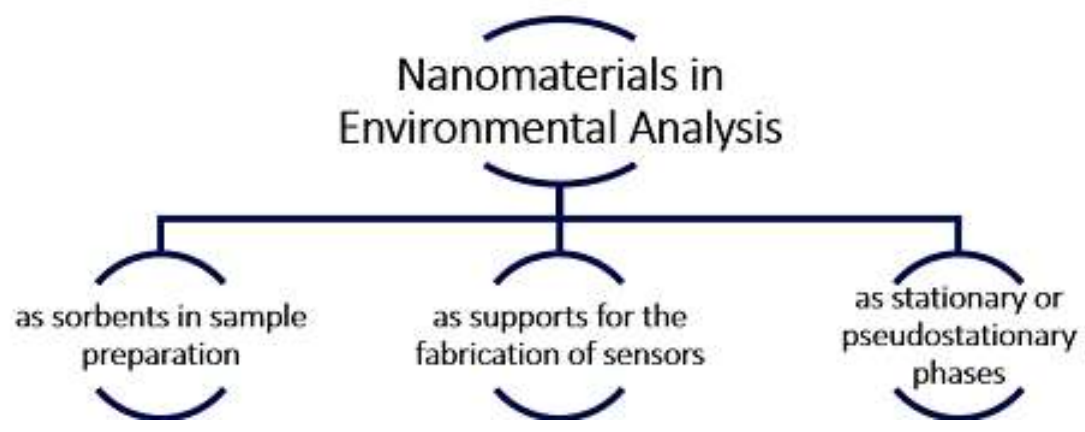

Fig. 11.4. General overview of the applications of nanomaterials in environmental samples analysis.

The low concentration of target analytes, the high content of potential interferents and the incompatibility of the sample matrix with the instrumental techniques are the main reasons behind the need of improving the sample preparation step, envisioning the enhancement of speed, reliability and sensitivity. The goals of sample preparation methods are summarized in Fig. 11.5 (Xu et al., 2016). Solid-phase extraction (SPE) is one of the most attractive procedures for sample preparation since it can be easily implemented, can be combined with different detection techniques and it holds high ability for preconcentration (Hussain and Kharisov, 2016). In SPE, nanomaterials, which will be discussed below, usually display a high performance for the adsorption of a wide range of analytes due to their high surface area and possibility of modifying their chemical nature and chemical groups at the surface.

\section{SAMPLE PREPARATION METHODS :}

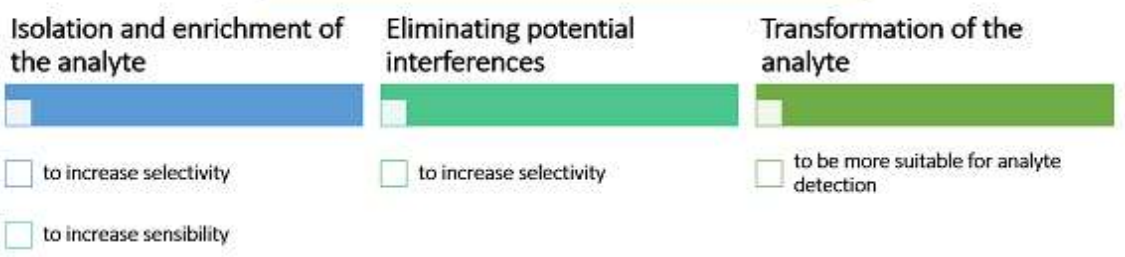

Fig. 11.5. Schematic representation of the main goals in the sample preparation step. 


\subsection{Nanomaterials in Solid-Phase Extraction}

As highlighted before, sample preparation is a crucial step in the analysis of aquatic environmental samples since these matrices tend to be highly complex, presenting most of the times trace level analytes (Ribeiro et al., 2014; Wierucka and Biziuk, 2014). Sample preparation is essential to improve the analytes concentration and to remove interfering species (Tian et al., 2013), contributing to the enhancement of both accuracy and sensitivity (Xu et al., 2016). In sample preparation procedures, the most common difficulties are related with the use of timeconsuming methodologies, complete recovery of the target analytes, removal or isolation of impurities, and high associated costs (Wierucka and Biziuk, 2014). It is highly desirable to improve the adsorption efficiency and selectivity, as well as the miniaturization and automation of various stages of sample preparation (Ribeiro et al., 2014; Wen et al., 2014; Wierucka and Biziuk, 2014).

Amongst the different preconcentration techniques for sample preparation, SPE is advantageous over other pretreatment techniques, like liquid-liquid extraction, precipitation, co-precipitation, etc. (Das, Gupta and Das, 2012). SPE is a simple and fast operation, it allows high enrichment factors and recovery, may be of low cost, and can avoid the consumption of organic solvents (Das, Gupta and Das, 2012). Some classic materials, such as C8 and C18, mixedmode/cationic-exchange (MCX), mixed-mode/anion-exchange (MAX) and weak anion-exchange (WAX), are commonly used in SPE (Wen et al., 2014). More recently, novel solidphase sorbents based mainly on nanomaterials have been studied and applied for water samples pretreatment in environmental analysis. Although several sample preparation methods using nanomaterials have been proposed, in this chapter the use of nanomaterials in SPE for monitoring of environmental aqueous samples and drinking water samples is reviewed.

The term "nanomaterials" (NMs) usually refers to materials with nanometric size (typically 1-100 nm), at least in one dimension (length, width or thickness) (Tian et al., 2013; Xu et al., 2016). Therefore, nanomaterials may include nanometer sized particles and materials with porous size in the nanometer range or even nanometer sized particles dispersed within a porous matrix (Tian et al., 2013) (Fig. 11.6 ). These NMs present exceptional physical and chemical properties, such as high specific areas, and the possibility of displaying unique optical, electrical, thermal and magnetic characteristics. They can also be functionalized with various chemical groups to increase their affinity toward target compounds and present various morphologies, being tuneable according to the type of analyte and analytical technique (Tian et al., 2013; Xu et al., 2016). 


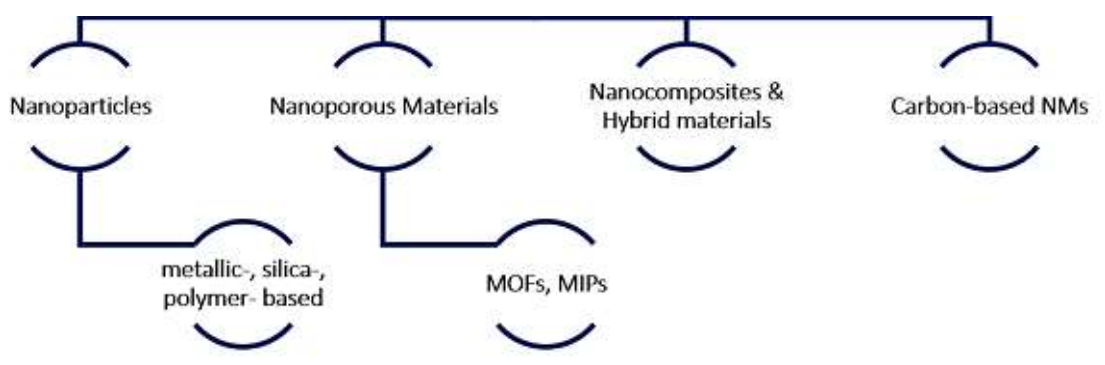

Fig. 11.6. Schematic representation of the different types of nanomaterials used in SPE for the analysis of environmental aqueous samples. MOFs: metal organic frame-work materials; MIPs: molecularly imprinted polymers.

During the past two decades, nanomaterials have been extensively employed to design novel pretreatment techniques focused on isolation and/or preconcentration of target analytes from different types of samples (Hussain and Kharisov, 2016). Herein, we summarize and discuss some of the latest (from 2009 to 2018) and most significant applications of nanomaterials in SPE for sample preparation, namely for environmental aqueous sample analysis. These NMs include metallic nanoparticles (MNPs), metal organic frame-work (MOF) materials, molecularly imprinted polymers (MIPs), carbonaceous nanomaterials and silica-based nanoparticles, which are described below in detail.

\subsubsection{Metallic Nanoparticles (MNPs) in SPE}

Metallic nanoparticles involve a wide range of different inorganic and inorganic/organic hybrid nanoparticles, such as metal nanoparticles, metal oxide nanoparticles and magnetic nanoparticles (Lucena et al., 2011; Tian et al., 2013).

Among metal nanoparticles, gold nanoparticles (Au NPs) and silver nanoparticles (Ag NPs) are the most well-known nanosorbents for metal ions and organic pollutants, such as PAHs (Wang and Campiglia, 2010; Lo et al., 2012; Wu, Lin and Tseng, 2012; Tian et al., 2013; Hussain and Kharisov, 2016). In the past decade, Liu (Liu, 2009) provided an overview on the characterization and applications of Au NPs, highlighting the incorporation of Au NPs in analytical systems, namely in the preparation and concentration of samples.

Au NPs are highly relevant in the field of environmental monitoring and analysis since organic molecules containing thiol (-SH) or amino $\left(-\mathrm{NH}_{2}\right)$ groups can adsorb spontaneously onto $\mathrm{Au}$ surfaces to form well-organized self-assembled monolayers (Liu, 2009). Accordingly, Wang and Campiglia (Wang and Campiglia, 2010) described the use of a gold nanoparticlebased SPE method for benzo[a]pyrene (PAH) determination in spiked tap water samples. The methodology was combined to laser-excited time-resolved Shpol'skii spectrometry (LETRSS), being able to improve the limit of detection (LOD) of the technique by an order of magnitude 
$(\mathrm{LOD}=0.001 \mathrm{ng} / \mathrm{mL})$ (Wang and Campiglia, 2010). In addition to organic compounds, Karimipour et al. (Karimipour et al., 2012) showed the applicability of Au NPs for the enrichment and preconcentration of trace amounts of metals, namely $\mathrm{Co}^{2+}, \mathrm{Cu}^{2+}, \mathrm{Ni}^{2+}, \mathrm{Fe}^{2+}, \mathrm{Pb}^{2+}$, and $\mathrm{Zn}^{2+}$, from real samples. By using a new sorbent based on Au NPs loaded in activated carbon (AuNP-AC) and modified by bis(4-methoxy salicylaldehyde)-1,2-phenylenediamine (BMSAPD), a preconcentration factor of 200 was reported for all the metal ions under study, with detection limits ranging from 1.4 to $2.6 \mathrm{ng} / \mathrm{mL}$ (Karimipour et al., 2012). Also, Lo et al. (Lo et al., 2012) tested the affinity of mercury species for Au NPs, namely by mixing Au NPs with aluminium oxide $\left(\mathrm{Al}_{2} \mathrm{O}_{3}\right)$ particles. The authors reported removal efficiencies higher than $97 \%$ for the four mercury species, from spiked lake water, groundwater, and seawater samples (Lo et al., 2012). Moreover, by using this $\mathrm{Au} \mathrm{NP}-\mathrm{Al}_{2} \mathrm{O}_{3}$ adsorbent it was found that the LODs for the mercury species were in the sub-ppq level, which is about 24 -fold lower than those obtained without preconcentration ( $\mathrm{LOD}=0.028 \mu \mathrm{g} / \mathrm{mL}$ ) (Lo et al., 2012).

Ag NPs have also been described as adsorbents with high affinity towards mercury. In this line, Wu et al. (Wu, Lin and Tseng, 2012) increased the selectivity (more than 1000-fold) of the analytical system for $\mathrm{Hg}^{2+}$ over other metal ions, by combining nanoparticle extraction, fluorescent dye labelling, and flow injection analysis (FIA) detection. Silver nanoparticles were functionalized with an oligonucleotide composed of repeated 33 thymine nucleotides $\left(\mathrm{T}_{33}-\right.$ AgNPs) that specifically captures $\mathrm{Hg}^{2+}$ from tap water samples (LOD $\left.=0.006 \mathrm{ng} / \mathrm{mL}\right)(\mathrm{Wu}$, Lin and Tseng, 2012). Not only surface modification with functional groups in Ag NPs provided extra selectivity, but also it prevents the prepared Ag NPs from aggregating (Tian et al., 2013).

Metal oxide nanoparticles (MONPs), such as $\mathrm{TiO}_{2}, \mathrm{Al}_{2} \mathrm{O}_{3}, \mathrm{ZnO}, \mathrm{ZrO}_{2}, \mathrm{MnO}$ and $\mathrm{CeO}_{2}$, have been reported in the literature as major inorganic nanoadsorbents for the enrichment and separation of metal trace elements (Lucena et al., 2011; Wen et al., 2014; Hussain and Kharisov, 2016). $\mathrm{TiO}_{2} \mathrm{NPs}$ were used for $\mathrm{Cd}$ determination from groundwater and wastewater samples at the nanogram per kilogram level with high preconcentration factors $(>10)$ (Garcíaruiz et al., 2011). As summarized in Table 11.1, several MONPs have been used to analyse metal ions in environmental aqueous samples (Afkhami et al., 2011; Baytak, Zereen and Arslan, 2011; Erdogan, Yalçinkaya and Türker, 2011; García-ruiz et al., 2011; Yalçinkaya et al., 2012). Most of the times these MONPs are modified with functional coatings to increase their selectivity (Lucena et al., 2011); for instance, Baytak et al. (Baytak, Zereen and Arslan, 2011) described the use of a minicolumn of a yeast (Yamadazyma spartinae) immobilized on $\mathrm{TiO}_{2}$ nanoparticles for the determination of $\mathrm{Cr}, \mathrm{Cu}, \mathrm{Fe}, \mathrm{Mn}, \mathrm{Ni}$ and $\mathrm{Zn}$ in environmental water samples by ICP-MS. Alumina $\left(\mathrm{Al}_{2} \mathrm{O}_{3}\right)$ nanoparticles were also successfully used for the determination of trace amounts of $\mathrm{Pb}(\mathrm{II})$ and $\mathrm{Cr}(\mathrm{III})$ in environmental water samples (Afkhami et al., 2011). Afkhami et al. (Afkhami et al., 2011) prepared modified MONPs by the immobilization of 2,4-dinitrophenylhydrazine on nano-alumina coated with sodium dodecyl sulphate, with recoveries of the metals ranging from 98 to $104 \%$ and a maximum preconcentration factor of 267 (Afkhami et al., 2011). 
Table 11.1. Summary on the use of metal oxide nanoparticles in SPE for metal ions detection (in the last 10 years). LOD: limit of detection; ID-ICPMS: inductively coupled plasma mass spectrometry; ICP-AES: inductively coupled plasma atomic emission spectrometry; FAAS: flame atomic absorption spectrometry; HGAAS: hydride generation atomic absorption spectrometry.

\begin{tabular}{|c|c|c|c|c|c|c|}
\hline $\begin{array}{l}\text { Metal oxide } \\
\text { NPs }\end{array}$ & Modification & Sample matrix & Analyte & $\begin{array}{l}\text { Analytical tech- } \\
\text { nique }\end{array}$ & LOD (ng/mL) & Ref. \\
\hline $\mathrm{TiO}_{2}$ & - & $\begin{array}{c}\text { Ground and waste } \\
\text { waters }\end{array}$ & $\mathrm{Cd}(\mathrm{II})$ & ID-ICPMS & - & (García-ruiz et al., 2011) \\
\hline $\mathrm{TiO}_{2}$ & $\begin{array}{l}\text { Coated with yeast } \\
\text { (Yamadazyma } \\
\text { spartinae) }\end{array}$ & $\begin{array}{c}\text { Tap and lake wa- } \\
\text { ters }\end{array}$ & $\begin{array}{c}\mathrm{Cr}(\mathrm{III}), \\
\mathrm{Cu}(\mathrm{II}), \\
\mathrm{Fe}(\mathrm{III}), \\
\mathrm{Mn}(\mathrm{II}), \\
\mathrm{Ni}(\mathrm{II}) \text { and } \\
\mathrm{Zn}(\mathrm{II})\end{array}$ & ICP-AES & $0.1-0.45$ & $\begin{array}{c}\text { (Baytak, Zereen and } \\
\text { Arslan, 2011) }\end{array}$ \\
\hline $\mathrm{Al}_{2} \mathrm{O}_{3}$ & $\begin{array}{l}\text { Coated with 2,4-dini- } \\
\text { trophenylhydrazine }\end{array}$ & $\begin{array}{l}\text { Tap, bottled min- } \\
\text { eral, waste waters, } \\
\text { industrial effluents }\end{array}$ & $\begin{array}{l}\mathrm{Pb}(\mathrm{II}) \text { and } \\
\mathrm{Cr}(\mathrm{III})\end{array}$ & FAAS & $0.43-0.55$ & (Afkhami et al., 2011) \\
\hline $\mathrm{ZrO}_{2}-\mathrm{B}_{2} \mathrm{O}_{3}$ & - & $\begin{array}{c}\text { Tap and hot spring } \\
\text { waters }\end{array}$ & $\begin{array}{l}\mathrm{As}(\mathrm{III}) \text { and } \\
\mathrm{As}(\mathrm{V})\end{array}$ & HGAAS & 0.009 & $\begin{array}{l}\text { (Erdogan, Yalçinkaya } \\
\text { and Türker, 2011) }\end{array}$ \\
\hline $\mathrm{ZrO}_{2}-\mathrm{B}_{2} \mathrm{O}_{3}$ & - & Waste water & $\mathrm{Al}(\mathrm{III})$ & FAAS & 7.71 & (Yalçinkaya et al., 2012) \\
\hline
\end{tabular}

Magnetic nanoparticles (MNPs) are constituted by a core and a supported layer, in which the magnetic core is mainly composed of iron, nickel, cobalt, and their corresponding oxides (Wierucka and Biziuk, 2014; Hussain and Kharisov, 2016). The most common magnetic cores are composed of iron oxides, including magnetite $\left(\mathrm{Fe}_{3} \mathrm{O}_{4}\right)$ and maghemite $\left(\mathrm{Fe}_{2} \mathrm{O}_{3}\right)$ (Hussain and Kharisov, 2016). Since pure iron-oxide NPs easily form aggregates, which may alter their magnetic properties, the surface of the magnetic core is usually modified with a suitable coating (Wen et al., 2014; Wierucka and Biziuk, 2014). The modifying layer can be either constituted by inorganic substances (e.g. silica, alumina, manganese oxide (IV), or graphene), organic substances (e.g. molecularly imprinted polymers, chitosan, divinylbenzene, polyamidoamines), or surfactants (Wierucka and Biziuk, 2014; Hussain and Kharisov, 2016). This coating layer protects not only the magnetic core from aggregation but also from oxidation and, if properly selected, may enhance the interaction between analytes and the adsorbent material.

Due to its several advantages, silica is the most commonly used material for coating MNPs. Silica carries silane groups that can be easily modified (Wierucka and Biziuk, 2014). Fig. 11.7 shows a scheme of the sol-gel process usually applied to synthetize silica-coated MNPs. Zhang 
et al. (Zhang et al., 2011) described the use of a core-shell magnetic $\left(\mathrm{Fe}_{3} \mathrm{O}_{4} / \mathrm{SiO}_{2}\right)$ mesoporous silica sorbent functionalized with $\mathrm{C}_{18}$ (octadecyltriethoxysilane) groups for the removal of PAHs from water samples. Also, surfactants such as sodium dodecyl sulphate (SDS) can be functionalized on the surface of MNPs, being suitable either for the adsorption of metal ions (mercury) (Faraji, Yamini and Rezaee, 2010) or antidepressant drugs (fluoxetine) (Bagheri, Zandi and Aghakhani, 2011). Moreover, some polymers and copolymers were described as coating agents of MNPs for the removal of toxic metal ions and organic compounds from environmental water samples and their pretreatment, such as polyaniline (Mehdinia, Roohi and Jabbari, 2011), a copolymer of methyl methacrylate (MMA) and maleic anhydride (MA) (Masoumi, Ghaemy and Bakht, 2014), polydopamine (Iqbal et al., 2011) and polypyrrole (Iqbal et al., 2011; Meng et al., 2011).

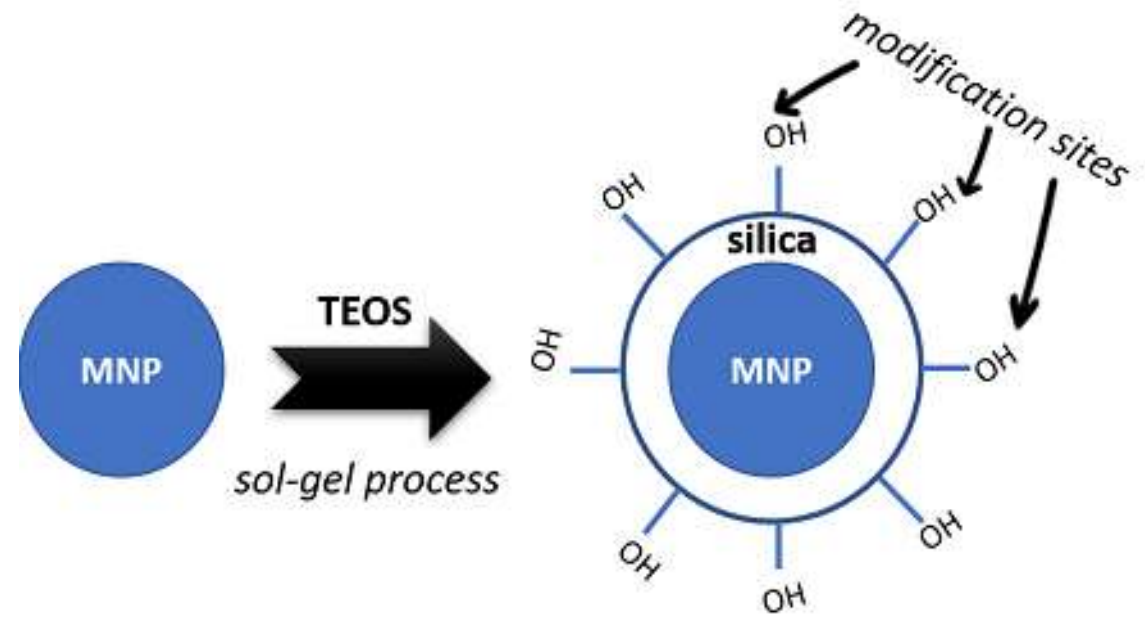

Fig. 11.7. Synthesis of silica-coated magnetic nanoparticles (MNPs), where hydroxyl groups could be then modified. TEOS: tetraethyl orthosilicate.

More recently, Tolmacheva et al. (Tolmacheva et al., 2016) suggested the use of a new generation of highly porous polymers, the hypercrosslinked polystyrene (HCP), for the modification of $\mathrm{Fe}_{3} \mathrm{O}_{4}$ NPs. This absorbent was used for the preconcentration of four sulphonamide antibiotics from river water samples. The compounds were quantified by high-performance liquid chromatography with amperometric detection, with recoveries varying between 84 and $97 \%$ and the detection limit ranging between 0.6 and $1.0 \mathrm{ng} / \mathrm{mL}$ (Tolmacheva et al., 2016). Ionic liquids (ILs) such as 3-chloropropyl-N-methylimidazolium (Yang et al., 2011) and 1hexadecyl-3-methylimidazolium bromide have also been successfully used to functionalize MNPs (Cheng et al., 2012), both works envisaging the preconcentration of chlorophenols in environmental water samples prior to HPLC-UV analysis. Table 11.2 compiles the latest uses of MNPs with different surface modifications in the preconcentration of several analytes in environmental water samples. 
The latest described works correspond to magnetic solid-phase extraction (MSPE). This method presents a clear advantage over simple SPE, explaining the increased interest of researchers in such an approach. With MNPs, the sorbent with the adsorbed analytes can be easily separated from the aqueous solution using an external magnetic field (magnet) without the need for sample centrifugation or filtration, thus contributing to a faster separation process (Fig. 11.8). Due to these benefits, other types of magnetic absorbents have been reported for sample preparation in environmental analysis of water samples, such as the magnetic metal-organic frameworks (MMOFs), magnetic molecularly imprinted polymers (MMIP) and carbon-based magnetic hybrid nanocomposites, which will be discussed further ahead in this chapter.

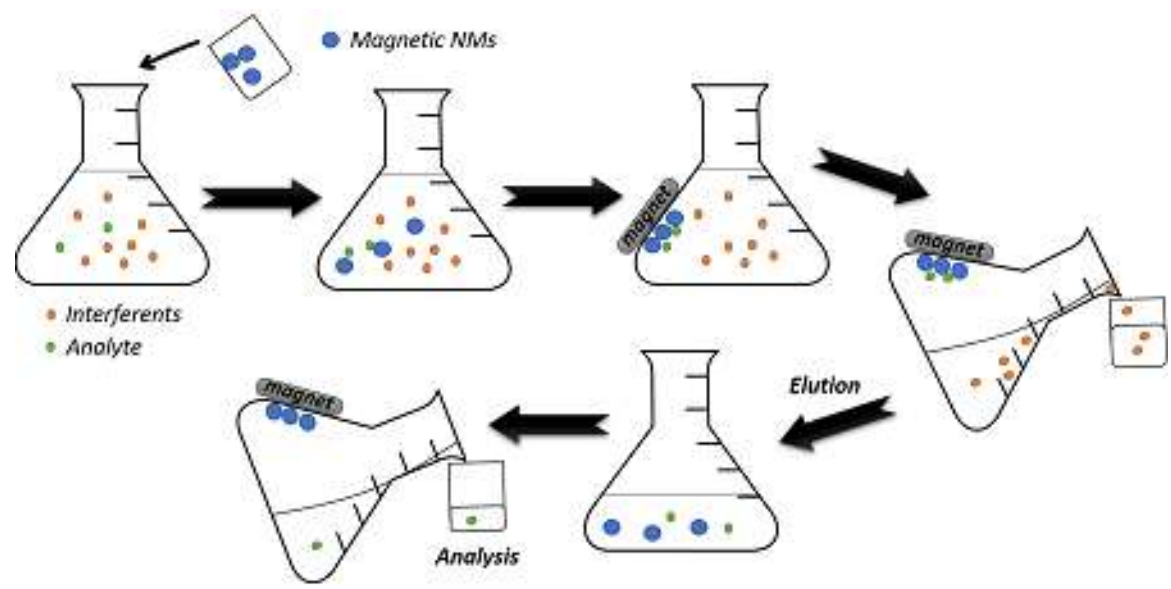

Fig. 11.8. Schematic representation of the MSPE procedure.

Table 11.2. Summary on the use of MSPE in the pretreatment of aqueous sample (in the last 10 years). LOD: limits of detection; SDS: sodium dodecyl sulphate; APTMS: 3-aminopropyltrimethoxysilane; HCP: hypercrosslinked polystyrene; ICP-OES: inductively coupled plasma optical emission spectrometry; LC-FD: liquid chromatography with fluorescence detection; GCMS: gas chromatography-mass spectrometry; CE-UV: capillary electrophoresis with UV-detection; HPLC: high-performance liquid chromatography; HPLC-PAD: HPLC with pulsed amperometric detection; HPLC-FD: HPLC with fluorescence detection; FAAS: flame atomic absorption spectrophotometry.

\begin{tabular}{ccllll}
\hline $\begin{array}{l}\text { Magnetic } \\
\text { Core }\end{array}$ & Covering layer & $\begin{array}{l}\text { Sample ma- Analyte } \\
\text { trix }\end{array}$ & $\begin{array}{l}\text { Analytical } \\
\text { technique }\end{array}$ & LOD (ng/mL) Ref. \\
\hline & SDS & $\begin{array}{l}\text { Tap, well } \\
\text { and mineral } \\
\text { water }\end{array}$ & ICP-OES & 0.04 & $\begin{array}{l}\text { (Faraji, Yamini and Re- } \\
\text { zaee, 2010) }\end{array}$ \\
$\mathrm{Fe}_{3} \mathrm{O}_{4}$ & SDS & $\begin{array}{l}\text { Tap and Fluoxetine } \\
\text { river water }\end{array}$ & LC-FD & 20 & $\begin{array}{l}\text { (Bagheri, Zandi and } \\
\text { Aghakhani, 2011) }\end{array}$ \\
\hline
\end{tabular}




\begin{tabular}{|c|c|c|c|c|c|c|}
\hline $\begin{array}{l}\text { Magnetic } \\
\text { Core }\end{array}$ & Covering layer & $\begin{array}{l}\text { Sample ma- } \\
\text { trix }\end{array}$ & - Analyte & $\begin{array}{l}\text { Analytical } \\
\text { technique }\end{array}$ & LOD $(\mathbf{n g} / \mathrm{mL})$ & Ref. \\
\hline & $\begin{array}{l}\text { Alkyl (C10-C18) } \\
\text { carboxylates }\end{array}$ & $\begin{array}{l}\text { River, reser- } \\
\text { voir and sea } \\
\text { water }\end{array}$ & $\begin{array}{l}\text { Benzo(a)pyrene, } \\
\text { benzo(b)-fluoranthene, } \\
\text { benzo(k)fluoranthene, } \\
\text { benzo(ghi)perylene and } \\
\text { indene(1,2,3-cd)pyrene } \\
\text { (PAHs) }\end{array}$ & LC-FD & $0.0002-0.0005$ & $\begin{array}{l}\text { (Ballesteros-Gomez and } \\
\text { Rubio, 2009) }\end{array}$ \\
\hline & Polyaniline & Seawater & Methylmercury & GC-MS & 0.1 & $\begin{array}{l}\text { (Mehdinia, Roohi and Jab- } \\
\text { bari, 2011) }\end{array}$ \\
\hline & $\begin{array}{l}\text { Polydopamine or } \\
\text { Polypyrrole }\end{array}$ & - & $\begin{array}{l}\text { Bisphenol A, proflavine, } \\
\text { naphthalene acetic acid }\end{array}$ & CE-UV & - & (Iqbal et al., 2011) \\
\hline & Polypyrrole & $\begin{array}{l}\text { Spiked wa- } \\
\text { ter }\end{array}$ & $\begin{array}{l}\text { Dimethyl phthalate, di- } \\
\text { ethylphthalate, di-iso- } \\
\text { butyl phthalate, di-n-bu- } \\
\text { tyl phthalate, benzyl- } \\
\text { butyl phthalate, di-(2- } \\
\text { ethylhexyl) phthalate } \\
\text { and di-n-octyl phthalate }\end{array}$ & GC-MS & $0.006-0.068$ & (Meng et al., 2011) \\
\hline & $\begin{array}{l}\text { APTMS and } \\
\text { poly(MMA-co- } \\
\text { MA) }\end{array}$ & - & $\begin{array}{l}\mathrm{Co}^{2+}, \mathrm{Cr}^{3+}, \mathrm{Zn}^{2+} \text {, and } \\
\mathrm{Cd}^{2+}\end{array}$ & - & - & $\begin{array}{l}\text { (Masoumi, Ghaemy and } \\
\text { Bakht, 2014) }\end{array}$ \\
\hline & $\mathrm{HCP}$ & River water & $\begin{array}{l}\text { Sulfamethoxypyridazine, } \\
\text { sulfamethazine, sulfa- } \\
\text { methoxazole and sul- } \\
\text { fachloropyridazine }\end{array}$ & HPLC-PDA & $0.6-1.0$ & (Tolmacheva et al., 2016) \\
\hline
\end{tabular}




\begin{tabular}{|c|c|c|c|c|c|c|}
\hline \multirow[t]{2}{*}{$\begin{array}{l}\text { Magnetic } \\
\text { Core }\end{array}$} & \multirow{2}{*}{$\begin{array}{l}\text { Covering layer } \\
\text { Silica }\end{array}$} & \multicolumn{2}{|c|}{$\begin{array}{l}\text { Sample ma-Analyte } \\
\text { trix }\end{array}$} & \multirow{2}{*}{$\begin{array}{l}\begin{array}{l}\text { Analytical } \\
\text { technique }\end{array} \\
\text { HPLC-PDA } \\
\end{array}$} & \multirow{2}{*}{$\begin{array}{r}\text { LOD }(\mathbf{n g} / \mathbf{m L}) \\
0.0028-0.0272\end{array}$} & \multirow{2}{*}{$\begin{array}{l}\text { Ref. } \\
\text { (Huo and Yan, 2012) }\end{array}$} \\
\hline & & $\begin{array}{l}\text { Lake and } \\
\text { waste water }\end{array}$ & $\begin{array}{l}\text { Maphthalene, acenaph- } \\
\text { sthene, anthracene, fluo- } \\
\text { ranthene, and pyrene, } \\
\text { benz[a]anthracene } \\
\text { (PAHs) }\end{array}$ & & & \\
\hline & $\begin{array}{l}\text { Silica and 3-chlo- } \\
\text { ropropyl-N-me- } \\
\text { thylimidazolium }\end{array}$ & \multicolumn{2}{|c|}{$\begin{array}{l}\text { River, spring3-chlorophenol, 2,4-di- } \\
\text { and tap wa- chlorophenol, pentachlo } \\
\text { ters } \quad \text { rophenol }\end{array}$} & HPLC & $0.20-0.35$ & (Yang et al., 2011) \\
\hline & $\begin{array}{l}\text { 1-hexadecyl-3-me- } \\
\text { thylimidazolium } \\
\text { bromide }\end{array}$ & $\begin{array}{l}\text { River and } \\
\text { tap water }\end{array}$ & $\begin{array}{l}\text { 2,4-dichlorophenol and } \\
\text { 2,4,6-trichlorophenol }\end{array}$ & HPLC & $0.12-0.13$ & (Cheng et al., 2012) \\
\hline & $\begin{array}{l}\text { C18-functionalized } \\
\text { mesoporous silica }\end{array}$ & $\begin{array}{l}\text { Spiked ultra } \\
\text { pure water }\end{array}$ & $\begin{array}{l}\text {-Fluoranthene, pyrene, } \\
\text { benzo(a)anthracene, } \\
\text { benzo[b]fluoranthene, } \\
\text { benzo(a)pyrene, } \\
\text { benzo[g,h,i]perylene } \\
\text { (PAHs) }\end{array}$ & HPLC-FD & - & (Zhang et al., 2011) \\
\hline & $\begin{array}{l}\text { Mesoporous silica } \\
(\mathrm{MCM}-41) \text { and } \\
\text { functionalization } \\
\text { with pyridine }\end{array}$ & $\begin{array}{l}\text { Tap, river } \\
\text { and sea wa- } \\
\text { ter }\end{array}$ & $\mathrm{Cd}^{2+}$ & FAAS & 0.04 & (Omidi et al., 2015) \\
\hline & $\begin{array}{l}\mathrm{Cu}_{3}(\mathrm{BTC})_{2} \mathrm{MOF} \\
\text { and functionaliza- } \\
\text { tion with dithizone }\end{array}$ & \multicolumn{2}{|c|}{$\begin{array}{l}\text { Tap and lake } \mathrm{Pb}^{2+} \\
\text { water } \\
\text { e }\end{array}$} & FAAS & 0.0046 & (Y. Wang et al., 2013) \\
\hline
\end{tabular}

\subsubsection{Metal organic frameworks (MOFs)}

In the last decade, a class of organic-inorganic hybrid microporous materials have emerged as improved absorbent materials in separation science, namely metal organic frameworks (MOFs) (Wen et al., 2014; Xu et al., 2016; Hashemi et al., 2017). MOFs are self-assembled materials composed of metal ions (or clusters) with organic linkers via coordination bonds 
(Tian et al., 2013; Wen et al., 2014; Hussain and Kharisov, 2016; Xu et al., 2016; Hashemi et al., 2017). Their inorganic moieties act as the nodes of 3-D frameworks with ligands as linkers that create a porous structure with stable and well-defined cavities (Hussain and Kharisov, 2016). Provided with a super large surface area, in the range between 1000 and $10000 \mathrm{~m}^{2} / \mathrm{g}$, MOFs can be a promising material in sample preparation (Xu et al., 2016). Moreover, by changing the structure or size of guests, these materials can exhibit different pore size and diverse topology, and their surfaces can be also easily functionalized (Tian et al., 2013). The diversity of either metal ions or organic linkers allows the design and preparation of new and different types of MOFs in terms of topology, structure, and porosity (Hashemi et al., 2017). In summary, MOFs are remarkable porous materials as they possess the robustness of their inorganic metal structure and the tuneability of polymer materials (Tian et al., 2013; Wen et al., 2014; Hussain and Kharisov, 2016; Xu et al., 2016; Hashemi et al., 2017)

Hashemi et al. (Hashemi et al., 2017) reviewed the available data on the use of MOFs for the separation of diverse organic and inorganic pollutants from several types of samples. The authors also described the chemical and physical features responsible for the high performance of this class of materials; metal ions are linked to organic ligands or organic secondary building units (SBU) by strong bonds, whereas the common inorganic secondary building units include metal clusters (e.g. metal-carboxylate clusters and metal-azolate clusters), metal atoms, or rodshaped clusters, and the common used organic linkers contains oxygen or nitrogen donors (e.g. carboxylates, azoles, nitriles, etc.) to offer linkage sites with inorganic SBU (Hashemi et al., 2017).

When dealing with water-based matrices, water-stable MOFs have to be considered, such as the "Material Institute Lavoisier" (MIL)-series MOFs (e.g. MIL-101(Cr), MIL-100(Fe), and MIL-53(M) (M: Fe, Al, and Cr), Zr-MOFs (e.g. UiO-66 and UiO-66-NH2), and zeolite imidazolate frameworks (ZIFs: e.g. ZIF-8) (Hashemi et al., 2017). Due to its excellent thermal and chemical stability, MIL-101(Cr) was widely used in diverse fields, such as in chromatography, catalysis, gas adsorption and in SPE (Li et al., 2014). Li et al. (Li et al., 2014) used MIL$101(\mathrm{Cr})$ as a SPE sorbent material combined with fast detection analysis in real time mass spectrometry (DART-MS) for the analysis of triazine herbicides from lake water samples. LODs for the five studied herbicides were below the $\mathrm{ng} / \mathrm{mL}$ level, meeting the regulatory requirements of the European Union (Li et al., 2014). Moreover, the recoveries were in the range of $85-110 \%$. The obtained high adsorption capacity is probably due to the $\pi-\pi$ interactions between the organic ligand network of the MOF and the phenyl ring of the target molecules ( $\mathrm{Li}$ et al., 2014). Another commonly used MOF, especially for metals recovery, is $\mathrm{Cu}_{3}(\mathrm{BTC})_{2}$ (BTC=benzene-1,3,5-tricarboxylate). Sohrabi (Sohrabi, 2014) reported a novel thiol-functionalized MOF, where thiol-functionalized silica NPs were incorporated in the $\mathrm{Cu}_{3}(\mathrm{BTC})_{2} \mathrm{MOF}$, for the removal and preconcentration of $\mathrm{Hg}$ (II) ions from environmental water samples. When compared with other solid-phases, this MOF sorbent allowed higher enrichment factors and lower LODs, reaching $20 \mathrm{pg} / \mathrm{mL}$ (Sohrabi, 2014).

MOFs can be used not only in SPE but also in the coating of fibers for solid-phase microextraction (SPME), as summarized in Fig. 11.9. Solid-phase microextraction (SPME) was proposed in 1990 (Arthur and Pawliszyn, 1990), integrating sampling and sample preparation in one step (Lucena et al., 2011; Ribeiro et al., 2014). SPME consists in the exposure of a small fused-silica fiber coated with an appropriate sorbent layer to a gas or liquid sample that can be easily coupled with chromatographic and electrophoretic techniques (Lucena et al., 2011; 
Ribeiro et al., 2014). Chen et al. (Chen et al., 2012) explored the application of MIL-53(Al, Cr, $\mathrm{Fe}$ ) as fiber coatings for the SPME-GC-MS/MS of 16 PAHs in environmental water samples. It was found that MIL-53(Al) showed the highest adsorption efficiency towards PAHs, where very low detection limits $(0.10 \mathrm{pg} / \mathrm{mL})$ were achieved. These materials were compared with commercial fibers, showing that the MIL-53(Al) coatings provide better results in terms of adsorption efficiency of PAHs, while being of lower cost and higher robustness (Chen et al., 2012).

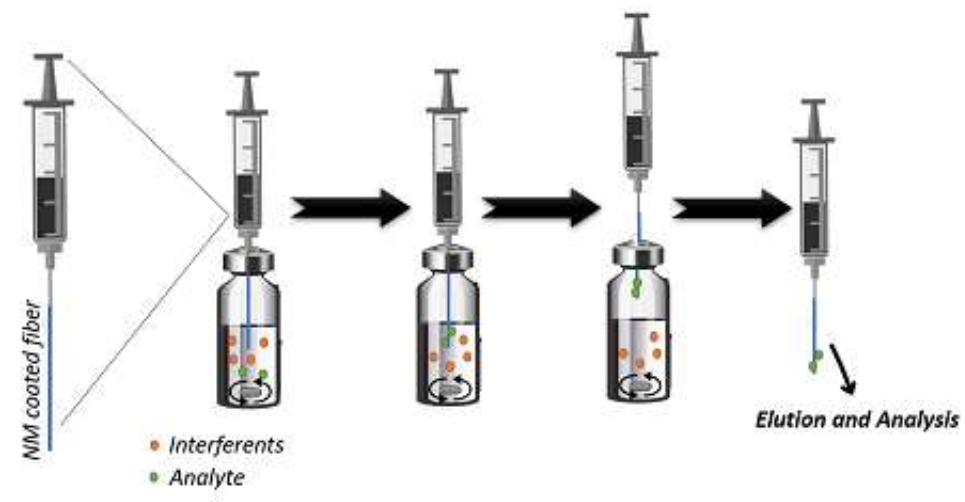

Fig. 11.9. Schematic representation of SPME by the direct immersion extraction mode.

Similar to SPME, stir bar sorptive extraction (SBSE) is an additional equilibrium technique, possessing significant advantages, such as high sensitivity and good reproducibility. Contrastingly, the coating amount on the stir bar is 50-250 times higher than that on SPME fibers, resulting in an increase in the adsorption and recovery values (Frank and Pat, 2007). Hu et al. (Hu et al., 2013) reported the synthesis of three novel PDMS/MOFs (MOF-5, MOF-199 and IRMOF-3) coatings by the sol-gel technique for the extraction of 7 estrogens from environmental water samples by SBSE. Under the optimal experimental conditions, LODs were found to be in the range of $0.15-0.35 \mathrm{ng} / \mathrm{mL}$ using the best-found material (PDMS/IRMOF-3), with enrichment factors ranging from 30.3 to 55.6 -fold (Hu et al., 2013).

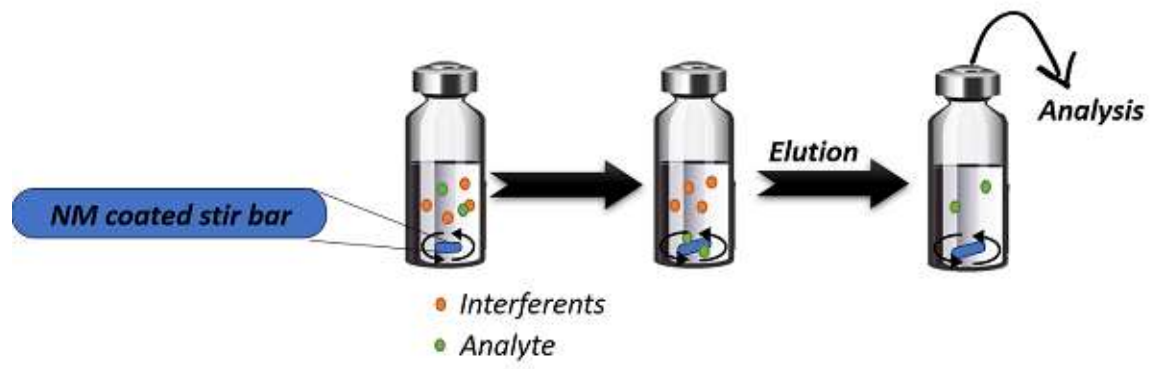

Fig. 11.10. Schematic representation of SBSE. 
Recently, composites of MOFs with magnetic NPs have also been developed for the preconcentration of different analytes using the MSPE technique. Wang et al. (Y. Wang et al., 2013) used dithizone ( $\mathrm{H} 2 \mathrm{Dz}, 1,5$-diphenylcarbazone), a commonly used chelating reagent that can form a stable complex with lead, to functionalize a magnetic $\mathrm{MOF}\left(\mathrm{Fe}_{3} \mathrm{O}_{4} / \mathrm{Cu}_{3}(\mathrm{BTC})_{2}\right)$. The developed method was applied for the preconcentration and determination of lead in environmental water samples, with recoveries in the range of $97-102 \%$ from real samples, and a detection limit as low as $0.0046 \mathrm{ng} / \mathrm{mL}$ (Y. Wang et al., 2013). Ma et al. (Ma et al., 2016) developed different kinds of magnetic MOFs for MSPE; for instance, they have reported a SPE procedure based on a magnetic porous carbon derived from an MOF for the preconcentration of steroid hormones from wastewater samples. In this approach, MIL-53-C was prepared through the direct carbonization of MIL-53, and the recoveries of the analytes for this novel methodology ranged from 96.2 to $98.7 \%$. This method was also compared with other reported ones for the determination of steroid hormones, being found that it had a similar or even better performance in terms of LOD $(0.005-0.01 \mathrm{ng} / \mathrm{mL})$ and recovery. In Table 11.3. the use of MOFs for the preconcentration of different analytes in environmental aqueous samples are summarized (in the last decade).

Table 11.3. Application of MOFs in SPE, SPME, SBSE and MSPE in environmental monitoring (in the last 10 years). LOD: limit of detection; HPLC: high-performance liquid chromatography; HPLC-PAD: HPLC with pulsed amperometric detection; DART-MS: direct analysis in real time-mass spectrometry; CVAAS; cold vapor atomic absorption spectroscopy; FAAS: flame atomic absorption spectrophotometry; GC-MS: gas chromatography-mass spectrometry; ETAAS: electrothermal atomic absorption spectrometry.

\begin{tabular}{|c|c|c|c|c|c|c|c|c|}
\hline MOFs & Metal & Modification & $\begin{array}{l}\text { Preconcen- } \\
\text { tration } \\
\text { technique }\end{array}$ & $\begin{array}{l}\text { Sample } \\
\text { matrix }\end{array}$ & Analyte & $\begin{array}{l}\text { Analyti- } \\
\text { cal tech- } \\
\text { nique }\end{array}$ & $\begin{array}{l}\text { LOD } \\
(\mathrm{ng} / \mathrm{mL} \\
)^{2}\end{array}$ & Ref. \\
\hline MOF-5 & $\mathrm{Zn}$ & - & SPE & $\begin{array}{l}\text { Tap, } \\
\text { spring and } \\
\text { river water }\end{array}$ & PAHs & $\begin{array}{l}\text { HPLC- } \\
\text { PDA }\end{array}$ & $\begin{array}{l}0.0004- \\
0.004\end{array}$ & $\begin{array}{l}\text { (S. } \\
\text {-Yang } \\
\text { et al., } \\
\text { 2013) }\end{array}$ \\
\hline MIL-101 & $\mathrm{Cr}$ & & SPE & Lake water & $\begin{array}{l}\text { Triazine } \\
\text { herbicides }\end{array}$ & $\begin{array}{l}\text { DART- } \\
\text { MS }\end{array}$ & $0.1-0.2$ & $\begin{array}{l}\text { (Li et } \\
\text { al., } \\
2014)\end{array}$ \\
\hline $\begin{array}{l}\text { ZIF-8 } \\
\text { (Zn(2-me- } \\
\text { thylimidaz- } \\
\text { ole)2) }\end{array}$ & $\mathrm{Zn}$ & - & SPE & $\begin{array}{l}\text { River wa- } \\
\text { ter }\end{array}$ & $\begin{array}{l}\text { 1H-benzotri- } \\
\text { azole, } 5 \text {-tol- } \\
\text { yltriazole }\end{array}$ & & - & $\begin{array}{l}\text { (Jiang, } \\
\text { Yang } \\
\text { and } \\
\text { Yan, } \\
2013 \text { ) }\end{array}$ \\
\hline $\mathrm{Cu} 3(\mathrm{BTC}) 2$ & $\mathrm{Cu}$ & $\begin{array}{l}\text { Thiol-modified } \\
\text { silica NPs }\end{array}$ & SPE & $\begin{array}{l}\text { River, tap, } \\
\text { waste wa- } \\
\text { ter and sea } \\
\text { water }\end{array}$ & $\mathrm{Hg}(\mathrm{II})$ & CV-AAS & 0.02 & $\begin{array}{l}\text { (Sohra } \\
\text { bi, } \\
\text { 2014) }\end{array}$ \\
\hline
\end{tabular}




\begin{tabular}{|c|c|c|c|c|c|c|c|c|}
\hline MOFs & Metal & Modification & $\begin{array}{l}\text { Preconcen- } \\
\text { tration } \\
\text { technique }\end{array}$ & $\begin{array}{l}\text { Sample } \\
\text { matrix }\end{array}$ & Analyte & $\begin{array}{l}\text { Analyti- } \\
\text { cal tech- } \\
\text { nique }\end{array}$ & $\begin{array}{l}\text { LOD } \\
(\mathrm{ng} / \mathrm{mL} \\
)^{2}\end{array}$ & Ref. \\
\hline $\begin{array}{l}{[\mathrm{Ag} 12} \\
\text { (MA)8(mal) } \\
6.18 \mathrm{H} 2 \mathrm{O}] \mathrm{n} \\
\text { MOF }\end{array}$ & $\mathrm{Ag}$ & - & SPE & $\begin{array}{l}\text { Distilled, } \\
\text { tap, river, } \\
\text { lake, waste } \\
\text { and sea } \\
\text { water }\end{array}$ & $\mathrm{Pb}(\mathrm{II})$ & FAAS & 0.5 & $\begin{array}{l}\text { (Salar- } \\
\text { ian et } \\
\text { al., } \\
2014 \text { ) }\end{array}$ \\
\hline MIL-53 & $\mathrm{Al}$ & - & SPME & $\begin{array}{l}\text { Waste wa- } \\
\text { ter }\end{array}$ & PAHs & $\begin{array}{l}\text { GC- } \\
\text { MS/MS }\end{array}$ & $\begin{array}{l}0.0001- \\
0.00073\end{array}$ & $\begin{array}{l}\text { (Chen } \\
\text { et al., } \\
2012)\end{array}$ \\
\hline MOF-5 & $\mathrm{Zn}$ & & & \multirow{3}{*}{$\begin{array}{l}\text { Lake, rive } \\
\text { and fish- } \\
\text { pond wa- } \\
\text { ters }\end{array}$} & \multirow{3}{*}{ Estrogens } & \multirow{3}{*}{ HPLC } & - & \multirow{3}{*}{$\begin{array}{l}\text { (Hu et } \\
\text { al., } \\
2013)\end{array}$} \\
\hline MOF-199 & $\mathrm{Zn}$ & $\begin{array}{l}\text { Polydime- } \\
\text { thylsiloxane }\end{array}$ & SBSE & & & & - & \\
\hline IRMOF-3 & $\mathrm{Cu}$ & & & & & & 0.35 & \\
\hline MIL-101 & $\mathrm{Cr}$ & $\begin{array}{l}\text { Addition of } \\
\mathrm{Fe}_{3} \mathrm{O}_{4} @ \mathrm{SiO}_{2}\end{array}$ & MSPE & $\begin{array}{l}\text { Lake and } \\
\text { waste wa- } \\
\text { ters }\end{array}$ & PAHs & $\begin{array}{l}\text { HPLC- } \\
\text { PDA }\end{array}$ & $\begin{array}{l}0.0028- \\
0.0272\end{array}$ & $\begin{array}{l}\text { (Huo } \\
\text { - and } \\
\text { Yan, } \\
\text { 2012) }\end{array}$ \\
\hline MIL-101 & $\mathrm{Cr}$ & $\begin{array}{l}\text { Addition of } \\
\mathrm{Fe}_{3} \mathrm{O}_{4} @ \mathrm{SiO}_{2}\end{array}$ & MSPE & $\begin{array}{l}\text { Reservoir, } \\
\text { river, and } \\
\text { seawater }\end{array}$ & $\begin{array}{l}\text { Pyrazole/ } \\
\text { pyrrole pes- } \\
\text { ticides }\end{array}$ & HPLC & $0.3-1.5$ & $\begin{array}{l}\text { (J. Ma } \\
\text { et al., } \\
2016)\end{array}$ \\
\hline MOF-177 & $\mathrm{Zn}$ & $\begin{array}{l}\text { Addition of } \\
\mathrm{Fe}_{3} \mathrm{O}_{4} @ \mathrm{SiO}_{2}\end{array}$ & MSPE & $\begin{array}{l}\text { River, lake } \\
\text { and waste } \\
\text { waters }\end{array}$ & Phenols & GC-MS & $\begin{array}{l}0.0168- \\
0.2083\end{array}$ & $\begin{array}{l}\text { (Wang } \\
\text {, Lei } \\
\text { and } \\
\text { Song, } \\
\text { 2014) }\end{array}$ \\
\hline $\begin{array}{l}\text { Magnetic } \\
\mathrm{MOF} \\
\left(\mathrm{Fe}_{3} \mathrm{O}_{4} / \mathrm{Cu}_{3}(\right. \\
\left.\mathrm{BTC})_{2}\right)\end{array}$ & $\mathrm{Cu}$ & Dithizone & MSPE & $\begin{array}{l}\text { Tap and } \\
\text { lake water }\end{array}$ & $\mathrm{Pb}(\mathrm{II})$ & ETAAS & 0.0046 & $\begin{array}{l}\text { (Y. } \\
\text { Wang } \\
\text { et al., } \\
2013 \text { ) }\end{array}$ \\
\hline $\begin{array}{l}\text { Magnetic } \\
\mathrm{MOF} \\
\left(\mathrm{Fe}_{3} \mathrm{O} 4 / \mathrm{Cu}_{3}(\right. \\
\left.\mathrm{BTC})_{2}\right)\end{array}$ & $\mathrm{Cu}$ & $\begin{array}{l}\mathrm{Fe}_{3} \mathrm{O}_{4} \mathrm{NPs} \text { with } \\
\text { Dithizone }\end{array}$ & MSPE & $\begin{array}{l}\text { Distilled, } \\
\text { tap, river, } \\
\text { sea and } \\
\text { mineral } \\
\text { water }\end{array}$ & $\begin{array}{l}\mathrm{Cd}(\mathrm{II}), \\
\mathrm{Pb}(\mathrm{II}), \mathrm{Ni}(\mathrm{II}) \\
\text { and } \mathrm{Zn}(\mathrm{II})\end{array}$ & FAAS & $0.12-1.2$ & $\begin{array}{l}\text { (Taghi } \\
2_{\text {zadeh }} \\
\text { et al. }, \\
2013 \text { ) }\end{array}$ \\
\hline $\begin{array}{l}\text { Magnetic } \\
\mathrm{MOF} \\
\left(\mathrm{Fe}_{3} \mathrm{O} 4 / \mathrm{Cu}_{3}(\right. \\
\left.\mathrm{BTC})_{2}\right)\end{array}$ & $\mathrm{Cu}$ & $\begin{array}{l}\mathrm{Fe}_{3} \mathrm{O}_{4} \mathrm{NPs} \text { with } \\
\text { pyrine }\end{array}$ & MSPE & $\begin{array}{l}\text { Tap, river } \\
\text { and sea } \\
\text { water }\end{array}$ & $\begin{array}{l}\mathrm{Cd}(\mathrm{II}) \text { and } \\
\mathrm{Pb}(\mathrm{II})\end{array}$ & FAAS & $0.2-1.1$ & $\begin{array}{l}\text { (Sohra } \\
\text { bi et } \\
\text { al., } \\
2013 \text { ) }\end{array}$ \\
\hline
\end{tabular}




\begin{tabular}{|c|c|c|c|c|c|c|c|c|}
\hline MOFs & Metal & Modification & $\begin{array}{l}\text { Preconcen- } \\
\text { tration } \\
\text { technique }\end{array}$ & $\begin{array}{l}\text { Sample } \\
\text { matrix }\end{array}$ & Analyte & $\begin{array}{l}\text { Analyti- } \\
\text { cal tech- } \\
\text { nique }\end{array}$ & $\begin{array}{l}\text { LOD } \\
(\mathrm{ng} / \mathrm{mL} \\
{ }^{2}\end{array}$ & Ref. \\
\hline $\begin{array}{l}\text { Magnetic } \\
\mathrm{MOF} \\
\left(\mathrm{Fe}_{3} \mathrm{O} 4 / \mathrm{Cu}_{3}(\right. \\
\left.\mathrm{BTC})_{2}\right)\end{array}$ & $\mathrm{Cu}$ & $\begin{array}{l}\mathrm{Fe}_{3} \mathrm{O}_{4} \mathrm{NPs} \text { with } \\
\text { pyrine }\end{array}$ & MSPE & $\begin{array}{l}\text { Distilled, } \\
\text { tap, River, } \\
\text { and min- } \\
\text { eral water }\end{array}$ & $\operatorname{Pd}(\mathrm{II})$ & FAAS & 0.37 & $\begin{array}{l}\text { (Bagh } \\
\text { eri et } \\
\text { al., } \\
2012)\end{array}$ \\
\hline MIL-53-C & $\mathrm{Fe}$ & $\begin{array}{l}\text { Carbonization } \\
\text { of the MIL-53 }\end{array}$ & MSPE & $\begin{array}{l}\text { Waste wa- } \\
\text { ter }\end{array}$ & Hormones & HPLC & $\begin{array}{l}0.005- \\
0.01\end{array}$ & $\begin{array}{l}\text { (R. } \\
\text { Ma et } \\
\text { al., } \\
\text { 2016) }\end{array}$ \\
\hline
\end{tabular}

\subsubsection{Molecularly imprinted polymers (MIPs)}

Molecularly imprinted polymers (MIPs) are a specific class of synthetic polymers that have been used as selective sorbents for SPE since 1994 (Sellergren, 1994), which can be tailormade for target analytes (Lucena et al., 2011; Hussain and Kharisov, 2016; Xu et al., 2016). These selective sorbent materials are built by the introduction of templates in order to form specific nanosized cavities or surface binding sites (Lucena et al., 2011; Xu et al., 2016). The main components for MIPs synthesis include a functional monomer, a cross-linking agent, a template, a reaction initiator and an appropriate solvent (Hussain and Kharisov, 2016). A reaction of copolymerization occurs, where the functional monomer forms a stable complex with the template, resulting in a three-dimensional crosslinked polymer (Hussain and Kharisov, 2016). After the template elution, imprinted pores/cavities are left in the polymer network that are sterically complementary to the target compounds (Lucena et al., 2011; Hussain and Kharisov, 2016). Fig. 11.11 shows a schematic representation of the MIPs synthesis. Regarding the templates, neutral organic molecules, ionic compounds and epitopes have been employed (Lucena et al., 2011). 


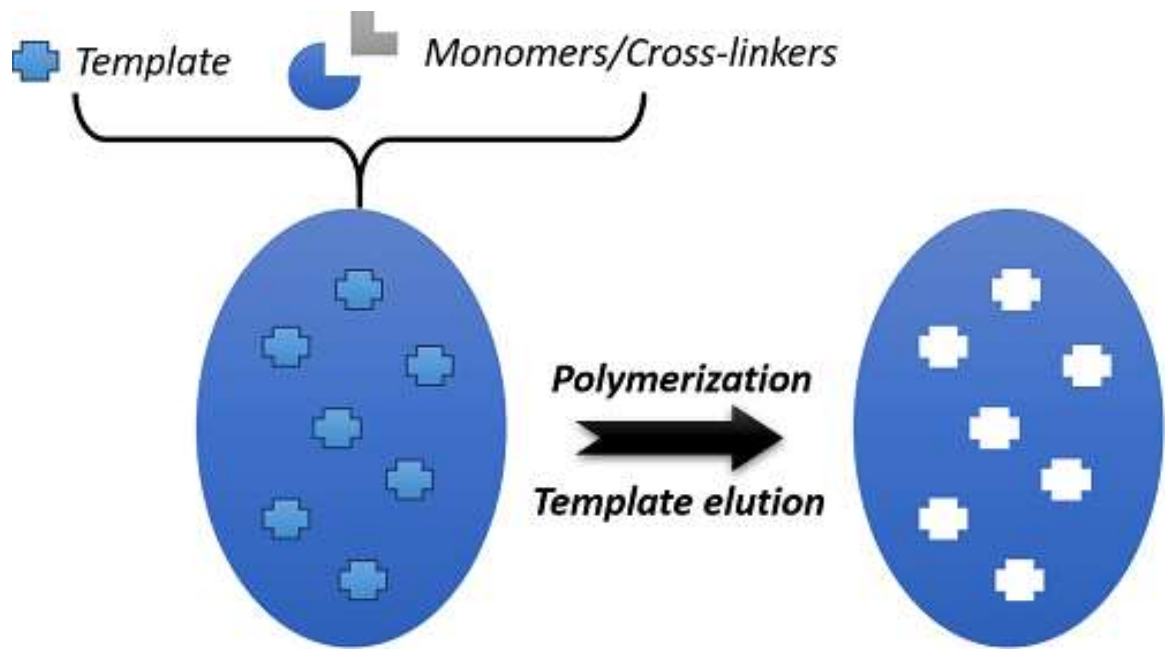

Fig. 11.11. Schematic representation for MIPs synthesis.

Due to the high specificity and selectivity of the molecular recognition mechanism of molecular imprinting, several studies regarding the applicability of MIPs for sample preparation have been carried out. Lian and Wang (Lian and Wang, 2016) reported a molecularly imprinted solid-phase extraction step followed by high-performance liquid chromatography with fluorescence detection for the clean-up, preconcentration and further analysis of ciprofloxacin, a fluoroquinolone antibiotic, in natural seawater samples. Ciprofloxacin was used as a template molecule and methacrylic acid was selected as the functional monomer because it was favourable for hydrogen bond recognition between the monomer and the target pollutant (Lian and Wang, 2016). The recoveries of spiked seawater on the prepared MIP-based cartridges ranged from 75.2 to $112.4 \%$ and the obtained LOD was $0.2 \mathrm{ng} / \mathrm{mL}$ (Lian and Wang, 2016). Canale et al. (Canale et al., 2010) reported a method to analyse bisphenol A (BPA), 17-b-estradiol (17 $\beta$-E2,) and ethynylestradiol (EE2) at ultratrace levels, with the goal of developing a screening procedure to monitor these endocrine-disrupting chemicals (EDCs) in environmental water samples. In their study, the fluorinated BPA derivative (4,40-(hexafluoroisopropylidene)-diphenol) was used as a mimic template, where the synthetized imprinted polymer (poly-4-VP-co-TRIM) showed high affinity and selectivity for BPA, 17 $\beta$-E2 and EE2, providing recoveries close to $100 \%$ and low LOD $(0.010 \mathrm{pg} / \mathrm{mL})$ for BPA in real drinking water samples (Canale et al., 2010).

Traditionally, the use of MIPs involves the loading of MIPs into SPE cartridges; however, more recently, MSPE became a popular extraction mode based on the use of MIPs that are grafted onto magnetic NPs. Ji et al. (Ji et al., 2009) and Chen et al. (Chen et al., 2010) prepared magnetic MIPs for the preconcentration and detection of BPA and fluoroquinolone antibiotics in environmental water samples. Additionally, both silica particles (Zhu et al., 2011; Song et al., 2012; Yin et al., 2012) and carbon nanotubes (Tan et al., 2011; Yang et al., 2013) can be an excellent support material of MIPs, especially MWCNTs due to their extremely large surface area (Wen et al., 2014). Accordingly, Tan et al. (Tan et al., 2011) and Yang et al. (Yang et al., 
2013) described the preparation of MIPs on the surface of MWCNTs for the determination of several herbicides in environmental water samples.

Table 11.4 lists some applications of MIPs in sample preparation and extraction of toxic analytes from environmental water samples.

Table 11.4. Application of MIPs in SPE, SPME, and MSPE for environmental monitoring (in the last 10 years). LOD: limit of detection; BPA: bisphenol A; TMB: 3,3',5,5'-tetramethylbenzidine; DPA: diphenolic Acid; TBBPA: tetrabromobisphenol A; 2,4-D: 2,4-dichlorophenoxyacetic acid; 17ロ-E2: 17-b-estradiol; EE2: ethynylestradiol; MMA: Methacrylic acid; EGDMA: ethylene glycol dimethacrylate; 4-VP: 4-vinylpyridine; TRIM: trimethylolpropane trimethacrylate; $\gamma$-MPTMS: $\gamma$-mercaptopropyltrimethoxysilane; TMOS: tetramethoxysilane; PTMS: propyltrimethoxysilane; TEOS: tetraethyl orthosilicate; APTES: (3-aminopropyl)triethoxysilane; HPLC: high-performance liquid chromatography; HPLC-FD: HPLC with fluorescence detection; CE-UV: capillary electrophoresis with UV-detection; GC-ECD: gas chromatography with electron capture detection; GCMS: gas chromatography-mass spectrometry; RRLC-DAD: reversed-phase rapid-resolution liquid-chromatography with photodiode array detection; HPLC-MS/MS: HPLC coupled with tandem mass spectrometry.

\begin{tabular}{|c|c|c|c|c|c|c|c|c|}
\hline Template & $\begin{array}{c}\text { Monomer/ } \\
\text { cross- } \\
\text { linker }\end{array}$ & Modification & $\begin{array}{l}\text { Sample } \\
\text { matrix }\end{array}$ & Analyte I & $\begin{array}{c}\text { Preconcentration } \\
\text { technique }\end{array}$ & $\begin{array}{c}\text { Analytical } \\
\text { technique }\end{array}$ & $\begin{array}{c}\text { LOD } \\
(\mathrm{ng} / \mathrm{mL})\end{array}$ & Ref. \\
\hline Ciprofloxacin & $\begin{array}{l}\text { MAA/ } \\
\text { EGDMA }\end{array}$ & & Seawater & Ciprofloxacin & SPE & HPLC-FD & 0.2 & $\begin{array}{c}\text { (Lian and } \\
\text { Wang, 2016) }\end{array}$ \\
\hline BPA & $\begin{array}{l}4-\mathrm{VP} / \\
\text { TRIM }\end{array}$ & & $\begin{array}{l}\text { Tap, waste } \\
\text { and river } \\
\text { waters }\end{array}$ & BPA & SPE & $\mathrm{CE}-\mathrm{UV}$ & $3.0-6.9$ & $\begin{array}{l}\text { (Mei et al., } \\
\text { 2011) }\end{array}$ \\
\hline TMB & $\begin{array}{c}\gamma- \\
\text { MPTMS/T } \\
\text { MOS }\end{array}$ & $\begin{array}{l}\text { Grafted on the } \\
\text { silica gel sur- } \\
\text { face }\end{array}$ & $\begin{array}{l}\text { Tap, lake } \\
\text { and sea wa- } \\
\text { ter }\end{array}$ & Biphenyls & SPE & GC-ECD & 1 & $\begin{array}{l}\text { (Zhu et al., } \\
\text { 2011) }\end{array}$ \\
\hline $\begin{array}{l}\text { Fluorinated } \\
\text { BPA deriva- } \\
\text { tive }\end{array}$ & $\begin{array}{l}4-\mathrm{VP} / \\
\text { TRIM }\end{array}$ & & $\begin{array}{l}\text { Potable wa- } \\
\text { ter }\end{array}$ & $\begin{array}{c}\text { BPA, } 17 \beta-\mathrm{E} 2, \\
\text { EE2 }\end{array}$ & SPE & GC-MS & 0.00001 & $\begin{array}{c}\text { (Canale } \text { et al. } \text {, } \\
\text { 2010) }\end{array}$ \\
\hline PAHs & $\begin{array}{l}\text { PTMS/ } \\
\text { TEOS }\end{array}$ & $\begin{array}{l}\text { Grafted on the } \\
\text { silica gel sur- } \\
\text { face }\end{array}$ & Seawater & PAHs & SPE & GC-MS & $\begin{array}{l}0.0052- \\
0.0126\end{array}$ & $\begin{array}{l}\text { (Song et al., } \\
\text { 2012) }\end{array}$ \\
\hline $\mathrm{DPA}$ or $\mathrm{BPA}$ & $\begin{array}{l}\text { APTES/ } \\
\text { TEOS }\end{array}$ & $\begin{array}{l}\text { Grafted on the } \\
\text { silica gel sur- } \\
\text { face }\end{array}$ & $\begin{array}{l}\text { Tap, river } \\
\text { and lake } \\
\text { water }\end{array}$ & TBBPA & SPE & RRLC-DAD & 2 & $\begin{array}{l}\text { (Yin et al., } \\
\text { 2012) }\end{array}$ \\
\hline
\end{tabular}




\begin{tabular}{|c|c|c|c|c|c|c|c|c|}
\hline Template & $\begin{array}{c}\text { Monomer/ } \\
\text { cross- } \\
\text { linker }\end{array}$ & Modification & $\begin{array}{l}\text { Sample } \\
\text { matrix }\end{array}$ & Analyte & $\begin{array}{c}\text { Preconcentration } \\
\text { technique }\end{array}$ & $\begin{array}{l}\text { Analytical } \\
\text { technique }\end{array}$ & $\begin{array}{c}\text { LOD } \\
(\mathrm{ng} / \mathrm{mL})\end{array}$ & Ref. \\
\hline Ciprofloxacin & $\begin{array}{l}\text { MAA/ } \\
\text { EGDMA }\end{array}$ & $\begin{array}{c}\text { Incorporated } \\
\text { with } \mathrm{Fe}_{3} \mathrm{O}_{4} \\
\mathrm{NPs}\end{array}$ & $\begin{array}{c}\text { Lake, river, } \\
\text { waste wa- } \\
\text { ters }\end{array}$ & $\begin{array}{l}\text { Fluoroquino- } \\
\text { lone antibiot- } \\
\text { ics }\end{array}$ & MSPE & $\begin{array}{l}\text { HPLC- } \\
\text { MS/MS }\end{array}$ & $\begin{array}{l}0.0032- \\
0.0062\end{array}$ & $\begin{array}{l}\text { (Chen et al., } \\
\text { 2010) }\end{array}$ \\
\hline BPA & $\begin{array}{c}\text { 2-VP } \\
\text { /EGDMA }\end{array}$ & $\begin{array}{c}\text { Incorporated } \\
\text { with Fe3O4 } \\
\text { NPs }\end{array}$ & $\begin{array}{c}\text { River and } \\
\text { waste water }\end{array}$ & BPA & MSPE & HPLC & 0.014 & $\begin{array}{l}\text { (Ji et al., } \\
\text { 2009) }\end{array}$ \\
\hline Prometryn & $\begin{array}{l}\text { MAA/ } \\
\text { TRIM }\end{array}$ & $\begin{array}{l}\text { Polymerized } \\
\text { on MWCNTs }\end{array}$ & $\begin{array}{c}\text { River and } \\
\text { waste water }\end{array}$ & $\begin{array}{l}\text { Triazine herb- } \\
\text { icides }\end{array}$ & SPME & HPLC & $0.08-0.38$ & $\begin{array}{l}\text { (Tan et al., } \\
\text { 2011) }\end{array}$ \\
\hline $2,4-\mathrm{D}$ & $\begin{array}{c}\text { Acrylamide } \\
\text { and styrene/ } \\
\text { EGDMA }\end{array}$ & $\begin{array}{l}\text { Polymerized } \\
\text { on } \mathrm{SiO}_{2-} \\
\text { coated } \\
\text { MWCNTs }\end{array}$ & River water & $2,4-\mathrm{D}$ & SPE & HPLC & 100 & $\begin{array}{l}\text { (W. Yang et } \\
\text { al., 2013) }\end{array}$ \\
\hline
\end{tabular}

\subsubsection{Carbon-based nanomaterials}

Carbon-based nanomaterials have been described in the literature as one of the most important trends in SPE technology (Wen et al., 2014). Carbon exists in various allotropes, such as fullerenes, carbon nanocones, carbon nanodisks, carbon nanofibers, carbon nanohorns, diamond, graphene (G) and graphene oxide (GO), and carbon nanotubes (CNTs), including single-walled CNTs (SWCNTs) and multi-wall CNTs (MWCNTs) (Tian et al., 2013; Wen et al., 2014; Xu et al., 2016). However, applications in environmental analysis, namely regarding sample preparation, have been mainly focused on the use of fullerenes, CNTs and G/GO (Tian et al., 2013; Wen et al., 2014).

The earliest report on carbon-based nanomaterials dates from 1985, when fullerene $\mathrm{C}_{60}$ was firstly prepared by Smalley et al. (Kroto et al., 1985). Nevertheless, only in 1994 Gallego et al. (Gallego, Pena and Valcarcel, 1994) fabricated a continuous-flow system using a $\mathrm{C}_{60}$ fullerene mini-column for the preconcentration of lead for environmental analysis (Wen et al., 2014; Xu et al., 2016). Fullerenes are polyhedral nanostructures, in a spherical arrangement, in which carbons are bonded to form five-to-six-membered rings (Lucena et al., 2011). They present a low tendency to form aggregates, and thus fullerenes are promising alternatives to be used as sorbents in SPE procedures based on continuous flow devices. In this perspective, JuradoSanchez et al. (Jurado-sánchez, Ballesteros and Gallego, 2009) described the use of fullerenes for aromatic and non-aromatic $\mathrm{N}$-nitrosamines separation. The authors compared the performance of $\mathrm{C}_{60}$ and $\mathrm{C}_{70}$ fullerenes and nanotubes, reporting that $\mathrm{C}_{60}$ fullerene is the best choice 
to selectively retain the aromatic fraction (sorption efficiency $>99 \%$ ). Fullerenes act as filters retaining only the aromatic fraction via $\pi-\pi$ interactions (Jurado-sánchez, Ballesteros and Gallego, 2009). Thus, by using an automatic system containing two sequential sorbent columns coupled to GC-MS, the quantification at the low nanogram per litter level of non-aromatic amines in drinking water and wastewater samples was possible, in which LODs of 0.004-0.012 ng/mL were reached (Jurado-sánchez, Ballesteros and Gallego, 2009).

Graphene is a single-atom-thick honeycomb two-dimensional lattice carbon nano-scaled material (Tian et al., 2013; Wen et al., 2014). Graphene exhibits a nanosheet structure with a large specific theoretical surface area and possesses a large delocalized $\pi$-electron system, offering a strong affinity for $\pi-\pi$ interactions with aromatic analytes. Due to these characteristics, it is a very popular option for use as an adsorbent material in SPE (Tian et al., 2013; Wen et al., 2014). Since many types of organic pollutants, such as PAHs, organophosphorus pesticides (OPPs), and phthalic acid esters (PAEs) hold aromatic residues, there are several available studies reported in the literature describing graphene as a good sorbent in SPE. For instance, Luo et al. (Luo et al., 2014) and $\mathrm{Wu}$ et al. (Wu et al., 2013) reported the use of graphene as a SPE sorbent for the determination of PAEs in environmental water samples, while Wang et al. (Z. Wang et al., 2013) used graphene in a SPE disks-based column for a fast separation and preconcentration of trace PAHs from environmental water samples. Different types of SPE approaches and analytical techniques were used in these studies. In the first study (Luo et al., 2014), graphene nanoplatelets were used as a novel sorbent material for a SPE cartridge to analyse PAEs by HPLC, showing that this method was highly effective for the extraction of target analytes with recoveries ranging from $87.7 \%$ to $100.9 \%$, being superior to other sorbents (C18 silica, HLB Oasis, activated carbon, and MWCNTs) (Luo et al., 2014). A simple and inexpensive method of dispersive solid-phase extraction (DSPE) combined GC-MS was used by Wu et al. (Wu et al., 2013), where graphene was dispersed into water samples in a centrifuge tube to adsorb PAEs; graphene was then isolated from the solution by centrifugation (recoveries between 71 and 117\%). Sun et al. (2014) (Sun et al., 2014) proposed a miniaturized self-assembly pipette tip graphene SPE cartridge (PT-G-SPE) coupled with liquid chromatography with fluorescence detection (LC-FD) for the preconcentration and determination of three sulphonamides in environmental water samples, allowing to reach detection limits in the range of $\mathrm{pg} / \mathrm{mL}$.

Graphene oxide (GO) is a monolayer of two-dimensional carbon-based materials, containing multi-functional groups, such as carboxyl, epoxy, ketone and hydroxyl groups, which can easily offer functionalized sites to enhance the selectivity for certain analytes (Tian et al., 2013; Wen et al., 2014). However, the direct use of graphene or GO as SPE adsorbents may rise several concerns, regarding aggregation or the leakage of the G or GO sheets from the SPE cartridges/columns (Liu et al., 2011). Therefore, new types of SPE sorbents produced by graphene bounded silica and graphene oxide bounded silica were introduced by Liu et al. (Liu et al., 2011), with this new material yielding excellent performance with recoveries of chlorophenols from water samples approaching $100 \%$. Recent applications of graphene in environmental sample preparation are summarized in Table 11.5. 
Table 11.5. Application of graphene nanomaterials in SPE for environmental monitoring (in the last 10 years). LOD: limit of detection; PAEs: phthalate esters; HPLC: high-performance liquid chromatography; FAAS: flame atomic absorption spectrometry; GC-MS: gas chromatography-mass spectrometry; HPLC-FD: HPLC with fluorescence detection; CE: capillary electrophoresis; AFS: atomic fluorescence spectrometry.

\begin{tabular}{|c|c|c|c|c|c|c|c|}
\hline $\begin{array}{l}\text { Carbon ma- } \\
\text { terial }\end{array}$ & Modification & Sample & Analyte & $\begin{array}{l}\text { Operation } \\
\text { mode }\end{array}$ & $\begin{array}{l}\text { Analytical } \\
\text { technique }\end{array}$ & $\begin{array}{l}\text { LOD } \\
(\mathrm{ng} / \mathrm{mL})\end{array}$ & Ref. \\
\hline $\begin{array}{l}\text { Graphene } \\
\text { nanoplatelets } \\
\text { (GN) }\end{array}$ & & $\begin{array}{l}\text { Tap and } \\
\text { commercial } \\
\text { bottled wa- } \\
\text { ter }\end{array}$ & PAEs & $\begin{array}{l}\text { SPE car- } \\
\text { tridge }\end{array}$ & HPLC & $0.09-0.33$ & 3 (Luo et al., 2014) \\
\hline Graphene & & $\begin{array}{l}\text { Tap, sea, } \\
\text { river, and } \\
\text { waste wa- } \\
\text { ters }\end{array}$ & $\mathrm{Pb}(\mathrm{II})$ & $\begin{array}{l}\text { SPE col- } \\
\text { umn }\end{array}$ & FAAS & 0.61 & (Wang et al., 2012) \\
\hline Graphene & & $\begin{array}{l}\text { Ultrapure, } \\
\text { river and } \\
\text { sea water }\end{array}$ & PAEs & DSPE & GC-MS & $2.0-6.0$ & (Wu et al., 2013) \\
\hline Graphene & & $\begin{array}{l}\text { Lake, river, } \\
\text { waste water }\end{array}$ & $\begin{array}{l}\text { Sulfonamide } \\
\text { rantibiotics }\end{array}$ & $\begin{array}{l}\text { SPE car- } \\
\text { tridge }\end{array}$ & HPLC-FD & $\begin{array}{l}0.0005- \\
0.0017\end{array}$ & (Sun et al., 2014) \\
\hline Graphene & & $\begin{array}{l}\text { Tap and } \\
\text { river water }\end{array}$ & PAHs & $\begin{array}{l}\text { SPE col- } \\
\text { umn }\end{array}$ & GC-MS & $\begin{array}{l}0.00084- \\
0.013\end{array}$ & $\begin{array}{l}\text { (Z. Wang et al., } \\
\text { 2013) }\end{array}$ \\
\hline $\begin{array}{l}\text { Graphene / } \\
\text { Graphene } \\
\text { oxide }\end{array}$ & $\begin{array}{l}\text { Bound to sil- } \\
\text { ica }\end{array}$ & & Chlorophenols & $\begin{array}{l}\text { SPE car- } \\
\text { tridge }\end{array}$ & MS & & (Liu et al., 2011) \\
\hline $\begin{array}{l}\text { Graphene } \\
\text { oxide }\end{array}$ & & $\begin{array}{l}\text { River and } \\
\text { sea water }\end{array}$ & \multicolumn{2}{|c|}{$\begin{array}{l}\text { ChlorophenoxySPE car- } \\
\text { acid herbicides tridge }\end{array}$} & $\mathrm{CE}$ & $0.3-0.5$ & (Tabani et al., 2013) \\
\hline
\end{tabular}




\begin{tabular}{|c|c|c|c|c|c|c|c|}
\hline $\begin{array}{l}\text { Carbon ma- } \\
\text { terial }\end{array}$ & Modificatio & nSample & Analyte & $\begin{array}{l}\text { Operation } \\
\text { mode }\end{array}$ & $\begin{array}{l}\text { Analytical } \\
\text { technique }\end{array}$ & $\begin{array}{l}\text { LOD } \\
\text { (ng/mL) }\end{array}$ & Ref. \\
\hline $\begin{array}{l}\text { Graphene } \\
\text { oxide }\end{array}$ & $\begin{array}{l}\text { Oxidized } \\
\text { with } \mathrm{H}_{2} \mathrm{SO}_{4}\end{array}$ & $\begin{array}{l}\text { River, la } \\
\text { and sea } \\
\text { ter }\end{array}$ & $\begin{array}{l}\mathrm{Pb}(\mathrm{II}), \mathrm{Cd}(\mathrm{II}) \\
-\mathrm{Bi}(\mathrm{III}) \text { and } \\
\mathrm{Sb}(\mathrm{III})\end{array}$ & SPE & AFS & $\begin{array}{l}0.002- \\
0.01\end{array}$ & (Deng et al., 2014) \\
\hline
\end{tabular}

Carbon nanotubes (CNTs) are amongst the most currently used nanomaterials for sample preparation in environmental analysis. CNTs can be described as a graphene sheet derived from the scrolling up into a nanoscale-tube (Tian et al., 2013; Wen et al., 2014). CNTs can be divided into single-walled carbon nanotubes (SWCNTs) and multi-walled carbon nanotubes (MWCNs). Like other carbon-based compounds, CNTs also exhibit good performance for the adsorption of several organic compounds (Yu et al., 2010; Hadjmohammadi, Peyrovi and Biparva, 2010; Katsumata et al., 2010; Ma et al., 2010; See et al., 2010; Wu et al., 2010; Guo et al., 2011; Herrera-herrera et al., 2011; Gao et al., 2012; Gonzalez-Curbelo et al., 2013; Lasarte-aragonés et al., 2013) and metal ions with or without chelating agents (Chen et al., 2009; Ozcan, Satiroglu and Soylak, 2010; El-sheikh et al., 2011; López-garcía, Rivas and Hernández-córdoba, 2011; Soylak and Unsal, 2012; Cui et al., 2012; Nabid et al., 2012; Behbahani et al., 2013; Soliman, Marwani and Albishri, 2013; Kocot et al., 2013; Madadizadeh, Taher and Ashkenani, 2013; Soylak and Topalak, 2014; Sahmetlioglu et al., 2014). Chen et al. (Chen et al., 2009) described the use of a microcolumn packed with SWCNTs as a new adsorption material for the preconcentration of trace metal ions in environmental samples. SWCNTs were first oxidized with nitric acid and filled into a PTFE microcolumn for the sample pretreatment, in which lake water samples were used. The levels of $\mathrm{Cu}, \mathrm{Co}$ and $\mathrm{Pb}$ ions present in the samples were determined by ICP-MS, reaching LOD values as low as $1.2 \mathrm{pg} / \mathrm{mL}$ (Chen et al., 2009).

The modification of CNTs with specific functional groups has been also adopted for sample preparation (Tian et al., 2013; Xu et al., 2016). Gao et al. (Gao et al., 2012) shown the applicability of cyano-functionalized MWCNTs for the preconcentration of phenolic compounds from river water and seawater samples. By using SPE cartridges filled with this cyano-functionalized MWCNTs adsorbent material, it was found that the limits of detection of the method were $0.45,0.09,0.08$, and $3.00 \mathrm{ng} / \mathrm{mL}$ for $p$-chlorophenol, 1-naphthol, 2-naphthol, and 2,4dichlorophenol, respectively (Gao et al., 2012). Furthermore, the functionalization of CNTs is also very valuable for metal ion analysis since several chelating reagents can be coupled to the surfaces of CNTs (Cui et al., 2012; Nabid et al., 2012; Behbahani et al., 2013; Madadizadeh, Taher and Ashkenani, 2013; Soliman, Marwani and Albishri, 2013; Sahmetlioglu et al., 2014; Soylak and Topalak, 2014). Cui et al. (Cui et al., 2012) covalently grafted phenyl-iminodiacetic acid groups onto MWCNTs for the preconcentration of trace quantities of several metal ions ( $\mathrm{Fe}$ (III), $\mathrm{Cu}$ (II) and $\mathrm{Pb}$ (II) ions) from tap and river water samples prior to their determination by ICP-OES. When compared with pristine (unmodified) MWCNTs, the functionalized PIAD- 
MWCNTs show better dispersibility in water and also higher sorption affinities for the tested metals (Cui et al., 2012). The recent applications of CNTs in SPE for the analysis of environmental water samples are summarized in Table 11.6.

Table 11.6. Application of CNTs in SPE for environmental monitoring (in the last 10 years). LOD: limit of detection; ICP-MS: inductively coupled plasma-mass spectrometry; FAAS: flame atomic absorption spectrometry; RRLC-DAD: RRLC-MS/MS: reversed-phase rapid-resolution liquid-chromatography coupled with tandem mass spectrometry; TRXF: total reflection X-ray fluorescence; CG-NPD: gas chromatography with nitrogen phosphorous detection; GC-MS: gas chromatography-mass spectrometry; Micro-LC: micro liquidchromatography; HPLC: high-performance liquid chromatography; ETAAS: electrothermal atomic absorption spectrometry; UPLC: ultra-performance liquid chromatography; CE-DAD: capillary electrophoresis with photodiode array detection; ICP-OES: inductively coupled plasma optical emission spectrometry.

\begin{tabular}{|c|c|c|c|c|c|c|}
\hline CNTs & Modification & Sample & Analyte & $\begin{array}{l}\text { Analytical } \\
\text { technique }\end{array}$ & $\begin{array}{l}\text { LOD } \\
(\mathrm{ng} / \mathrm{mL})\end{array}$ & Ref. \\
\hline SWNTs & $\begin{array}{l}\text { Oxidized with } \\
\text { nitric acid }\end{array}$ & Lake water & $\begin{array}{l}\mathrm{r} \text { Cu(II), } \mathrm{Co}(\mathrm{II}) \\
\text { and } \mathrm{Pb}(\mathrm{II})\end{array}$ & ICP-MS & $0.0012-0.039$ & $\begin{array}{l}\text { (Chen } e t \\
\text { al., 2009) }\end{array}$ \\
\hline MWCNTs & - & $\begin{array}{l}\text { Fortified } \\
\text { lake, tap, } \\
\text { and bottled } \\
\text { mineral } \\
\text { water }\end{array}$ & $\begin{array}{l}\mathrm{Fe}(\mathrm{III}), \mathrm{Cu}(\mathrm{II}) \\
\mathrm{Mn}(\mathrm{II}) \text { and } \\
\mathrm{Pb}(\mathrm{II})\end{array}$ & FAAS & $3.5-8.0$ & $\begin{array}{l}\text { (Ozcan, } \\
\text { Satiroglu } \\
\text { and Soy- } \\
\text { lak, 2010) }\end{array}$ \\
\hline MWCNTs & - & $\begin{array}{l}\text { River wa- } \\
\text { ter }\end{array}$ & $\begin{array}{l}\text { Triazine herbi- } \\
\text { cides }\end{array}$ & RRLC-MS/MS & 0.0001 & $\begin{array}{l}\text { (Yu et al., } \\
2010 \text { ) }\end{array}$ \\
\hline MWCNTs & - & $\begin{array}{l}\text { Sea, river } \\
\text { and waste } \\
\text { water }\end{array}$ & $\begin{array}{l}\mathrm{Cd}(\mathrm{II}) \text { and } \\
\mathrm{Pb}(\mathrm{II})\end{array}$ & TXRF & $1.0-2.1$ & $\begin{array}{l}\text { (Kocot et } \\
\text { al., 2013) }\end{array}$ \\
\hline MWCNTs & - & $\begin{array}{l}\text { Run-off, } \\
\text { mineral } \\
\text { and tap } \\
\text { water }\end{array}$ & $\begin{array}{l}\text { Organophos- } \\
\text { phorus pesti- } \\
\text { cides }\end{array}$ & GC-NPD & $\begin{array}{l}0.00116- \\
0.0936\end{array}$ & $\begin{array}{l}\text { (Gonza- } \\
\text { lez- } \\
\text { Curbelo et } \\
\text { al., 2013) }\end{array}$ \\
\hline MWCNTs & - & $\begin{array}{l}\text { Tap, river } \\
\text { and sea } \\
\text { water }\end{array}$ & $\begin{array}{l}\text { Triazine herbi- } \\
\text { cides }\end{array}$ & GC-MS & $0.0025-0.005$ & $\begin{array}{l}\text { (Katsu- } \\
\text { mata } \text { et } \\
\text { al., 2010) }\end{array}$ \\
\hline MWCNTs & - & $\begin{array}{l}\text { River, tap } \\
\text { and sea } \\
\text { waters }\end{array}$ & PAHs & GC-MS & $0.002-0.0085$ & $\begin{array}{l}\text { (Ma et al., } \\
2010)\end{array}$ \\
\hline MWCNTs & - & $\begin{array}{l}\text { River wa- } \\
\text { ter }\end{array}$ & $\begin{array}{l}\text { Triazine herbi- } \\
\text { cides }\end{array}$ & Micro-LC & $0.2-0.5$ & $\begin{array}{l}\text { (See et al., } \\
2010 \text { ) }\end{array}$ \\
\hline
\end{tabular}




\begin{tabular}{|c|c|c|c|c|c|c|}
\hline MWCNTs & - & $\begin{array}{l}\text { River wa- } \\
\text { ter }\end{array}$ & PAHs & GC-MS & $0.001-0.15$ & $\begin{array}{l}\text { (Wu et al., } \\
2010 \text { ) }\end{array}$ \\
\hline MWCNTs & - & $\begin{array}{l}\text { Fortified } \\
\text { lake, well } \\
\text { and waste } \\
\text { water }\end{array}$ & $\begin{array}{l}\mathrm{Fe}(\mathrm{III}) \text { and } \\
\mathrm{Pb}(\mathrm{II})\end{array}$ & FAAS & $1.3-2.9$ & $\begin{array}{l}\text { (Soylak } \\
\text { and Unsal, } \\
\text { 2012) }\end{array}$ \\
\hline MWCNTs & - & $\begin{array}{l}\text { Tap, well } \\
\text { and river } \\
\text { water }\end{array}$ & $\begin{array}{l}\text { Chlorpyrifos } \\
\text { and phosalone } \\
\text { pesticides }\end{array}$ & HPLC & $0.403-3.03$ & $\begin{array}{l}\text { (Hadjmo- } \\
\text { hammadi, } \\
\text { Peyrovi } \\
\text { and } \\
\text { Biparva, } \\
\text { 2010) }\end{array}$ \\
\hline MWCNTs & - & $\begin{array}{l}\text { Bottled } \\
\text { mineral, } \\
\text { tap, river } \\
\text { and sea } \\
\text { water }\end{array}$ & $\begin{array}{l}\text { As (III, V) and } \\
\text { Sb (III, V) }\end{array}$ & ETAAS & $0.02-0.05$ & $\begin{array}{l}\text { (López- } \\
\text { garcía, Ri- } \\
\text { vas and } \\
\text { Hernán- } \\
\text { dez-cór- } \\
\text { doba, } \\
2011 \text { ) }\end{array}$ \\
\hline MWCNTs & - & $\begin{array}{l}\text { Tap and } \\
\text { river water }\end{array}$ & $\begin{array}{l}\text { Linear al- } \\
\text { kylbenzene sul- } \\
\text { fonates }\end{array}$ & -HPLC & $0.02-0.03$ & $\begin{array}{l}\text { (Guo et } \\
\text { al., 2011) }\end{array}$ \\
\hline MWCNTs & & $\begin{array}{l}\text { River, well } \\
\text { and tap } \\
\text { water }\end{array}$ & $\begin{array}{l}{ }^{1} \text { Triazine herbi- } \\
\text { cides }\end{array}$ & UPLC & $0.15-0.40$ & $\begin{array}{l}\text { (Lasarte- } \\
\text { aragonés } \\
\text { et al., } \\
\text { 2013) }\end{array}$ \\
\hline MWCNTs & $\begin{array}{l}\text { Oxidized with } \\
\text { nitric acid }\end{array}$ & $\begin{array}{l}\text { Commer- } \\
\text { cial min- } \\
\text { eral, tap } \\
\text { and waste } \\
\text { water }\end{array}$ & $\begin{array}{l}\text { Quinolone anti- } \\
\text { biotics }\end{array}$ & CE-DAD & $0.028-0.094$ & $\begin{array}{l}\text { (Herrera- } \\
\text { herrera et } \\
\text { al., 2011) }\end{array}$ \\
\hline MWCNTs & $\begin{array}{l}\text { Oxidized with } \\
\text { nitric acid }\end{array}$ & $\begin{array}{l}\text { Tap, reser- } \\
\text { voir and } \\
\text { mineral } \\
\text { waters }\end{array}$ & $\mathrm{Hg}(\mathrm{II})$ ions & - & - & $\begin{array}{l}\text { (El-sheikh } \\
\text { et al., } \\
\text { 2011) }\end{array}$ \\
\hline MWCNTs & $\begin{array}{l}\text { Oxidized with } \\
\text { nitric acid and } \\
\text { 2-(5-bromo-2- } \\
\text { pyridylazo)-5- } \\
\text { diethylamino- } \\
\text { phenol modifi- } \\
\text { cation }\end{array}$ & $\begin{array}{l}\text { River, } \\
\text { waste and } \\
\text { sea waters }\end{array}$ & $\mathrm{Cd}(\mathrm{II})$ ions & ETAAS & 0.00014 & $\begin{array}{l}\text { (Madadi- } \\
\text { zadeh, } \\
\text { Taher and } \\
\text { Ashke- } \\
\text { nani, } \\
2013 \text { ) }\end{array}$ \\
\hline MWCNTs & $\begin{array}{l}\text { Immobilization } \\
\text { of 5-aminsali- } \\
\text { cylic acid }\end{array}$ & $\begin{array}{l}\text { Distilled, } \\
\text { tap, sea } \\
\text { and waste } \\
\text { water }\end{array}$ & $\mathrm{Pb}(\mathrm{II})$ ions & ICP-OES & 0.25 & $\begin{array}{l}\text { (Soliman, } \\
\text { Marwani } \\
\text { and Al- } \\
\text { bishri, } \\
\text { 2013) }\end{array}$ \\
\hline
\end{tabular}




\begin{tabular}{|c|c|c|c|c|c|c|}
\hline MWCNTs & $\begin{array}{l}\text { Tartrazine im- } \\
\text { pregnated }\end{array}$ & $\begin{array}{l}\text { Tap, min- } \\
\text { eral and } \\
\text { lake water }\end{array}$ & $\begin{array}{l}\mathrm{Cd}(\mathrm{II}) \text { and } \\
\mathrm{Pb}(\mathrm{II}) \text { ions }\end{array}$ & FAAS & $0.8-6.6$ & $\begin{array}{l}\text { (Soylak } \\
\text { and To- } \\
\text { palak, } \\
\text { 2014) }\end{array}$ \\
\hline MWCNTs & $\begin{array}{l}\text { Polypyrrole } \\
\text { coating }\end{array}$ & $\begin{array}{l}\text { Well and } \\
\text { wastewater }\end{array}$ & $\mathrm{r} P(\mathrm{II})$ ions & FAAS & 1.1 & $\begin{array}{l}\text { (Sahmetli- } \\
\text { oglu et al., } \\
\text { 2014) }\end{array}$ \\
\hline MWCNTs & $\begin{array}{l}\text { Poly(2-amino } \\
\text { thiophenol) } \\
\text { coating }\end{array}$ & $\begin{array}{l}\text { Distilled, } \\
\text { tap, river, } \\
\text { lake and } \\
\text { waste wa- } \\
\text { ters }\end{array}$ & $\begin{array}{l}\mathrm{Cd}(\mathrm{II}) \text { and } \\
\mathrm{Pb}(\mathrm{II}) \text { ions }\end{array}$ & FAAS & $0.3-10$ & $\begin{array}{l}\text { (Nabid et } \\
\text { al., 2012) }\end{array}$ \\
\hline MWCNTs & $\begin{array}{l}\text { Cyano-func- } \\
\text { tionalized }\end{array}$ & $\begin{array}{l}\text { River and } \\
\text { sea waters }\end{array}$ & $\begin{array}{l}\text { Phenolic com- } \\
\text { pounds }\end{array}$ & HPLC & $0.08-3.00$ & $\begin{array}{l}\text { (Gao et } \\
\text { al., 2012) }\end{array}$ \\
\hline MWCNTs & $\begin{array}{l}\text { Diphenylcarba- } \\
\text { zide functional- } \\
\text { ized }\end{array}$ & $\begin{array}{l}\text { Distilled, } \\
\text { tap, river, } \\
\text { and waste } \\
\text { waters }\end{array}$ & $\mathrm{Cd}(\mathrm{II})$ ions & FAAS & 0.05 & $\begin{array}{l}\text { (Behba- } \\
\text { hani et al., } \\
\text { 2013) }\end{array}$ \\
\hline MWCNTs & $\begin{array}{l}\text { Phenyl-iminodi- } \\
\text { acetic-acid } \\
\text { functionalized }\end{array}$ & $\begin{array}{l}\text { Tap and } \\
\text { river water }\end{array}$ & $\begin{array}{r}\mathrm{Fe}(\mathrm{III}), \mathrm{Cu}(\mathrm{II}) \\
\text { and } \mathrm{Pb}(\mathrm{II}) \text { ions }\end{array}$ & ICP-OES & $0.15-0.26$ & $\begin{array}{l}\text { (Cui et al., } \\
\text { 2012) }\end{array}$ \\
\hline
\end{tabular}

\subsubsection{Silica-based nanomaterials}

Silica-based nanomaterials for sample preparation include silica nanoparticles $\left(\mathrm{SiO}_{2} \mathrm{NPs}\right)$, and mesoporous silica materials (e.g. MCM-41 and SBA-15). These silica-based materials are characterized by high surface areas and high adsorption capacity (Lucena et al., 2011; Tian et al., 2013). Moreover, compared with other materials, silica-based NMs provide good biocompatibility (Xu et al., 2016) and are also easy to synthesize. Because they display intrinsic surface reactivity, it is possible to easily introduce functional groups on the surface (Lucena et al., 2011; Tian et al., 2013). Most of the silica-based materials are chemically modified when used as SPE sorbents or used as a support in other nanomaterials to form composites/hybrid materials (Gao et al., 2010; Bagheri, Ayazi and Aghakhani, 2011; Zhang et al., 2011; Zhu et al., 2011; Liu et al., 2011; Yang et al., 2011; Song et al., 2012; Yin et al., 2012; W. Wang et al., 2013; Mehdinia et al., 2014; Sohrabi, 2014; Omidi et al., 2015).

Rao et al. (Rao et al., 2016) tested the adsorption capacity of silica NPs in the pre-concentration of residues of pyrethroid pesticides in water samples. Spiked water samples were passed through silica NPs-filled cartridges for the simultaneous determination of the pesticide residues using GC-EI-MS (Rao et al., 2016). It was then found that silica NPs-based cartridges exhibit higher capacity to trap pesticides when compared with conventional C18 cartridges, leading also to a low LOD value of $0.05 \mathrm{ng} / \mathrm{mL}$ (Rao et al., 2016). Additionally, silica gel was used as a support material in SPE to extract and preconcentrate metal ions from environmental water 
samples. In particular, Leopold et al. (Leopold, Foulkes and Worsfold, 2009) reported the use of gold-coated silica as a preconcentration method for the determination of mercury in river water samples. Due to the high potential of nanogold surfaces for the adsorption of mercury species from aqueous solutions, the gold-coated silica nanomaterials proved to be highly efficient for the adsorption of different mercury species from acidified waters without using chelating agents, with recoveries higher than 90\% (Leopold, Foulkes and Worsfold, 2009). The microcolumn filled with gold-coated silica was then coupled to atomic fluorescence spectrometry (AFS), resulting in a low detection limit, of $0.18 \mathrm{pg} / \mathrm{mL}$ (Leopold, Foulkes and Worsfold, 2009). The application of silica-supported ionic liquids (ILs) in SPE has also been reported, namely in the preconcentration of trace metal ions from water samples. Liang and Peng (Liang and Peng, 2010) and Ayata et al. (Ayata, Bozkurt and Ocakoglu, 2011) described the preparation of a microcolumn packed with IL-modified silica combined with flame atomic absorption spectrometry (FAAS) for the determination of trace amounts of cadmium and lead in environmental water samples. The 1-butyl-3-methylimidazolium hexafluorophosphate (Liang and Peng, 2010) and the 1-methyl-3-butylimidazolium bromide (Ayata, Bozkurt and Ocakoglu, 2011) ILs were used to modify the silica surface for the determination of trace amount of metal ions in lake, tap water and river water samples with satisfactory results (LOD $=0.6 \mathrm{ng} / \mathrm{mL}$ (Liang and Peng, 2010) and $0.7 \mathrm{ng} / \mathrm{mL}$ (Ayata, Bozkurt and Ocakoglu, 2011)). A summary of the materials and applications of silica-based nanomaterials in SPE in the last decade are listed in Table 11.7.

Table 11.7. Application of silica-based nanomaterials in SPE for environmental monitoring (in the last 10 years). LOD: limit of detection; GC-MS: gas chromatography-mass spectrometry; AFS: atomic fluorescence spectrometry; UPLC: ultra-performance liquid chromatography; FAAS: flame atomic absorption spectrometry.

\begin{tabular}{|c|c|c|c|c|c|c|}
\hline Type of material & Functionalization & $\begin{array}{c}\text { Sample } \\
\text { matrix }\end{array}$ & Analyte & $\begin{array}{l}\text { Analytical } \\
\text { technique }\end{array}$ & $\begin{array}{c}\text { LOD } \\
(\mathrm{ng} / \mathrm{mL})\end{array}$ & Ref. \\
\hline Silica NPs & - & $\begin{array}{c}\text { Water sam- } \\
\text { ples }\end{array}$ & $\begin{array}{l}\text { Pyrethroid } \\
\text { pesticides }\end{array}$ & GC-MS & 0.05 & $\begin{array}{l}\text { (Rao et al. } \\
\text { 2016) }\end{array}$ \\
\hline Silica NPs & Resacetophenone & River water & $\mathrm{Pb}(\mathrm{II})$ & UV & 0.58 & $\begin{array}{l}\text { (Kaur and } \\
\text { Gupta, } \\
\text { 2009) }\end{array}$ \\
\hline Silica gel & Gold deposition & $\begin{array}{l}\text { Estuary and } \\
\text { river water }\end{array}$ & $\mathrm{Hg}(\mathrm{II})$ & AFS & 0.00018 & $\begin{array}{l}\text { (Leopold, } \\
\text { Foulkes and } \\
\text { Worsfold, } \\
\text { 2009) }\end{array}$ \\
\hline Silica gel & $\begin{array}{l}\text { Hydrophobic IL } \\
\text { (SG-1,10- } \\
\text { PhenanNTf2) }\end{array}$ & $\begin{array}{c}\text { Ground, } \\
\text { lake and } \\
\text { waste water }\end{array}$ & Coumarin & HPLC & & $\begin{array}{l}\text { (Marwani } \\
\text { and Bakhsh, } \\
\text { 2013) }\end{array}$ \\
\hline Silica gel & $\begin{array}{l}\text { 1-butyl-3-me- } \\
\text { thylimidazolium } \\
\text { hexafluorophos- } \\
\text { phate }\end{array}$ & $\begin{array}{l}\text { Lake and } \\
\text { tap water }\end{array}$ & $\mathrm{Cd}(\mathrm{II})$ & FAAS & 0.6 & $\begin{array}{l}\text { (Liang and } \\
\text { Peng, 2010) }\end{array}$ \\
\hline
\end{tabular}




\begin{tabular}{|c|c|c|c|c|c|c|}
\hline Type of material & Functionalization & $\begin{array}{c}\text { Sample } \\
\text { matrix }\end{array}$ & Analyte & $\begin{array}{c}\text { Analytical } \\
\text { technique }\end{array}$ & $\begin{array}{c}\text { LOD } \\
(\mathrm{ng} / \mathrm{mL})\end{array}$ & Ref. \\
\hline Silica gel & $\begin{array}{l}\text { 1-methyl-3-bu- } \\
\text { tylimidazolium } \\
\text { bromide }\end{array}$ & River water & $\mathrm{Pb}(\mathrm{II})$ & FAAS & 0.7 & $\begin{array}{l}\text { (Ayata, } \\
\text { Bozkurt and } \\
\text { Ocakoglu, } \\
2011 \text { ) }\end{array}$ \\
\hline $\begin{array}{l}\text { Mesoporous silica } \\
\text { particles (UVM-7) }\end{array}$ & Triethanolamine & $\begin{array}{l}\text { Tap, river } \\
\text { and waste } \\
\text { water }\end{array}$ & $\mathrm{Cr}(\mathrm{VI})$ & FAAS & 1.2 & $\begin{array}{l}\text { (Shirkhanloo } \\
\text { et al., 2015) }\end{array}$ \\
\hline
\end{tabular}

\subsection{Conclusions}

The contamination of the aquatic environment is a serious concern, which has negative impacts on the ecosystem and human health. To better address this concern, environmental monitoring is mandatory. However, most of the ubiquitous pollutants are close or under the detection limits of the currently available analytical techniques. There is thus a crucial need on improving the sample preparation step, envisioning the enhancement of speed, reliability and sensitivity of analysis. In this chapter, the most recent applications of nanomaterials in SPE for environmental water samples pretreatment were described and discussed. These NMs include metallic and magnetic nanoparticles, MOFs, MIPs, and carbonaceous- and silica-based nanomaterials.

In general, nanomaterials exhibit relevant physical and chemical properties, making of them superior candidates as sorbents in sample preparation techniques. Furthermore, the ability of nanomaterials for surface modification with a wide variety of functional groups promotes higher adsorption efficiencies and selectivity, while decreasing the limits of detection of the analytical techniques. All these features turn possible the analysis of several toxic compounds that are found in ultratrace levels in water samples.

In addition to the described NMs, in the future it is expected that new nanomaterials emerge in sample preparation techniques. It is also expected that an increasing number of novel nanocomposites and/or hybrid nanomaterials will appear by combining advantageous properties of the different types of nanomaterials. For instance, the use of composite/hybrid materials containing MNPs combined with MIPs, MOFs, CNTs, graphene, among others, are an example of such new solutions, further allowing an easy recovery by an external magnetic field without the need of centrifugation or filtration steps.

Among the most recent functional groups in NMs, ionic liquids (ILs) have emerged as a new class of sorbents coatings in SPE, named as supported ionic-liquid phases (SILPs). ILs are described as designer solvents, and can be widely modulated by altering their cation/anion chemical structures, thus allowing the establishment of specific interactions with the target analyte and the improvement on analysis. Although their numerous advantages, the use of SILPs in the pretreatment of samples for environmental monitoring is still in its infancy. 
A new trend in analytical chemistry and environmental monitoring is focused on the development of more sustainable pretreatment methods and analysis. To this end, it is necessary to eliminate, or at least to reduce, the amounts of organic solvents used in sample preparation techniques. Moreover, the recovery and reuse of solvents and/or nanomaterials, and the techniques automatization and miniaturization, are also major issues to improve.

Presently, most of the applications of nanomaterials for sample preparation in water environmental analysis are focused on metal ions, toxic organic compounds and pesticides. Nonetheless, due to their current serious concerns, pharmaceutical drugs and endocrine disrupting chemicals need to be more deeply addressed in the future.

\section{Acknowledgements}

This work was developed within the scope of the project CICECO-Aveiro Institute of Materials, FCT Ref. UID/CTM/50011/2019, financed by national funds through the FCT/MCTES. This work was financially supported by the project POCI-01-0145-FEDER-031106 (IonCytDevice) funded by FEDER, through COMPETE2020 - Programa Operacional Competitividade e Internacionalização (POCI), and by national funds (OE), through FCT/MCTES, and developed in the scope of the "Smart Green Homes" Project [POCI-01-0247-FEDER-007678], a copromotion between Bosch Termotecnologia S.A. and the University of Aveiro. It is financed by Portugal 2020 under the Competitiveness an Internationalization Operational Program, and by the European Regional Development Fund. A.C.A.S. acknowledges University of Aveiro, for funding in the scope of the framework contract foreseen in the numbers 4, 5 and 6 of the article 23, of the Decree-Law 57/2016, of August 29, changed by Law 57/2017, of July 19. M. C. N. acknowledges FCT, I.P. for the research contract CEECIND/00383/2017 under the CEEC Individual 2017.

\section{References}

Afkhami, A. et al. (2011) 'Flame atomic absorption spectrometric determination of trace amounts of $\mathrm{Pb}$ (II) and $\mathrm{Cr}$ (III) in biological, food and environmental samples after preconcentration by modified nano-alumina', Microchim Acta, 172, pp. 125-136. doi: 10.1007/s00604-010-0478-y.

Akpor, O. B. (2014) 'Heavy metal pollutants in wastewater effluents: sources, effects and remediation', Adv. Biosci. Bioeng., 2, p. 37.

Arthur, C. L. and Pawliszyn, J. (1990) 'Solid phase microextraction with thermal desorption using fused silica optical fibers', Anal. Chem., 62(19), pp. 2145-2148.

Ayata, S., Bozkurt, S. S. and Ocakoglu, K. (2011) 'Separation and preconcentration of Pb (II) using ionic liquid-modified silica and its determination by flame atomic absorption spectrometry', Talanta. Elsevier B.V., 84, pp. 212-215. doi: 10.1016/j.talanta.2011.01.006.

Bagheri, H., Ayazi, Z. and Aghakhani, A. (2011) 'A novel needle trap sorbent based on 
carbon nanotube-sol-gel for microextraction of polycyclic aromatic hydrocarbons from aquatic media', Analytica Chimica Acta. Elsevier B.V., 683(2), pp. 212-220. doi: 10.1016/j.aca.2010.10.026.

Bagheri, H., Zandi, O. and Aghakhani, A. (2011) 'Extraction of fluoxetine from aquatic and urine samples using sodium dodecyl sulfate-coated iron oxide magnetic nanoparticles followed by spectrofluorimetric determination', Analytica Chimica Acta. Elsevier B.V., 692(1-2), pp. 80-84. doi: 10.1016/j.aca.2011.02.060.

Baytak, S., Zereen, F. and Arslan, Z. (2011) 'Preconcentration of trace elements from water samples on a minicolumn of yeast (Yamadazyma spartinae) immobilized $\mathrm{TiO} 2$ nanoparticles for determination by ICP-AES', Talanta, 84, pp. 319-323. doi: 10.1016/j.talanta.2011.01.020.

Behbahani, M. et al. (2013) 'Application of multiwalled carbon nanotubes modified by diphenylcarbazide for selective solid phase extraction of ultra traces Cd (II) in water samples and food products', Food Chemistry. Elsevier Ltd, 141, pp. 48-53. doi: 10.1016/j.foodchem.2013.03.011.

Bjørklund, G. et al. (2017) 'The toxicology of mercury: Current re-search and emerging trends', Environ Res., 159(Supplement C), pp. 545-554.

Burgess, R. M., Ahrens, M. J. and Hickey, C. W. (2003) 'Geochemistry of PAHs in Aquatic Environments: Source, Persistence and Distribution', in PAHs: An Ecotoxicological Perspective.

Canale, F. et al. (2010) 'Development of a molecularly imprinted polymer for selective extraction of bisphenol A in water samples', J. Sep. Sci., 33, pp. 1644-1651. doi: $10.1002 /$ jssc. 201000013 .

Carolin, C. F. et al. (2017) 'Efficient techniques for the removal of toxic heavy metals from aquatic environment: A review', Journal of Environmental Chemical Engineering, 5, pp. 2782 2799. doi: 10.1016/j.jece.2017.05.029.

Chen, L. et al. (2010) 'Determination of fluoroquinolone antibiotics in environmental water samples based on magnetic molecularly imprinted polymer extraction followed by liquid chromatography-tandem mass spectrometry', Analytica Chimica Acta. Elsevier B.V., 662(1), pp. 31-38. doi: 10.1016/j.aca.2010.01.001.

Chen, S. et al. (2009) 'Solid-phase extraction of $\mathrm{Cu}, \mathrm{Co}$ and $\mathrm{Pb}$ on oxidized single-walled carbon nanotubes and their determination by inductively coupled plasma mass spectrometry', Journal of Hazardous Materials, 170, pp. 247-251. doi: 10.1016/j.jhazmat.2009.04.104.

Chen, X. et al. (2012) 'Metal-organic framework MIL-53 (Al) as a solid-phase microextraction water samples by gas chromatography-tandem mass spectrometry', Analyst, 137, pp. 5411-5419. doi: 10.1039/c2an35806a.

Cheng, Q. et al. (2012) 'Mixed hemimicelles solid-phase extraction of chlorophenols in environmental water samples with 1-hexadecyl-3-methylimidazolium bromide-coated Fe3O4 magnetic nanoparticles with high-performance liquid chromatographic analysis', Analytica Chimica Acta. Elsevier B.V., 715, pp. 113-119. doi: 10.1016/j.aca.2011.12.004.

Cui, Y. et al. (2012) 'Novel phenyl-iminodiacetic acid grafted multiwalled carbon nanotubes for solid phase extraction of iron, copper and lead ions from aqueous medium', Microchim Acta, 176, pp. 359-366. doi: 10.1007/s00604-011-0725-x.

Das, D., Gupta, U. and Das, A. K. (2012) 'Recent developments in solid phase extraction in elemental speciation of environmental samples with special reference to aqueous solutions', Trends in Analytical Chemistry. Elsevier Ltd, 38, pp. 163-171. doi: 10.1016/j.trac.2011.01.020. 
El-sheikh, A. H. et al. (2011) 'Effect of oxidation and geometrical dimensions of carbon nanotubes on $\mathrm{Hg}$ (II) sorption and preconcentration from real waters', Desalination. Elsevier B.V., 270, pp. 214-220. doi: 10.1016/j.desal.2010.11.048.

Erdogan, H., Yalçinkaya, Ö. and Türker, A. R. (2011) 'Determination of inorganic arsenic species by hydride generation atomic absorption spectrometry in water samples after preconcentration/ separation on nano ZrO2/B2O3 by solid phase extraction', Desalination, 280, pp. 391-396. doi: 10.1016/j.desal.2011.07.029.

European Commission (2013) Directive 2013/39/EU of the European Parliament and of the Council amending Directives 2000/60/EC and 2008/105/EC as regards priority substances in the field of water policy.

FAO, (Food and Agriculture Organization) (2017) Water pollution from agriculture: $a$ global review. Available at: http://www.fao.org/3/a-i7754e.pdf.

Faraji, M., Yamini, Y. and Rezaee, M. (2010) 'Extraction of trace amounts of mercury with sodium dodecyle sulphate-coated magnetite nanoparticles and its determination by flow injection inductively coupled plasma-optical emission spectrometry', Talanta. Elsevier B.V., 81, pp. 831-836. doi: 10.1016/j.talanta.2010.01.023.

Frank, D. and Pat, S. (2007) 'Stir bar sorptive extraction for trace analysis', Journal of Chromatography A, 1152(1-2), pp. 54-69.

Gallego, M., Pena, Y. P. de and Valcarcel, M. (1994) 'Fullerenes as Sorbent Materials for Metal Preconcentration', Anal. Chem., 66(22), pp. 4074-4078.

Gao, R. et al. (2010) 'Synthesis and evaluation of molecularly imprinted core-shell carbon nanotubes for the determination of triclosan in environmental water samples', Journal of Chromatography A. Elsevier B.V., 1217(52), pp. 8095-8102. doi: 10.1016/j.chroma.2010.10.121.

Gao, W. et al. (2012) 'Preparation of cyano-functionalized multiwalled carbon nanotubes as solid-phase extraction sorbent for preconcentration of phenolic compounds in environmetal water', J. Sep. Sci., 35, pp. 1967-1976. doi: 10.1002/jssc.201200045.

García-ruiz, S. et al. (2011) 'Cadmium determination in natural waters at the limit imposed by European legislation by isotope dilution and TiO2 solid-phase extraction', Anal. Bioanal. Chem., 401, pp. 2785-2792. doi: 10.1007/s00216-011-5256-0.

Gonzalez-Curbelo, M. A. et al. (2013) 'Analysis of pesticides residues in environmental water samples using multiwalled carbon nanotubes dispersive solid-phase extraction', J. Sep. Sci., 36, pp. 556-563. doi: 10.1002/jssc.201200782.

Guo, P. et al. (2011) 'Determination of linear alkylbenzene sulfonates by ion-pair solidphase extraction and high-performance liquid chromatography', Talanta. Elsevier B.V., 84, pp. 587-592. doi: 10.1016/j.talanta.2011.01.014.

Hadjmohammadi, M. R., Peyrovi, M. and Biparva, P. (2010) 'Comparison of C 18 silica and multi-walled carbon nanotubes as the adsorbents for the solid-phase extraction of Chlorpyrifos and Phosalone in water samples using HPLC', J. Sep. Sci., 33, pp. 1044-1051. doi: $10.1002 /$ jssc. 200900494.

Hashemi, B. et al. (2017) 'Metal-organic frameworks as advanced sorbents for the extraction and determination of pollutants from environmental, biological, and food media', Trends in Analytical Chemistry. Elsevier Ltd, 97, pp. 65-82. doi: 10.1016/j.trac.2017.08.015.

Herrera-herrera, A. V et al. (2011) 'Oxidized multi-walled carbon nanotubes for the dispersive solid-phase extraction of quinolone antibiotics from water samples using capillary 
electrophoresis and large volume sample stacking with polarity switching, Journal of Chromatography A. Elsevier B.V., 1218(31), pp. 5352-5361. doi: 10.1016/j.chroma.2011.06.031.

Hu, C. et al. (2013) 'Polydimethylsiloxane/metal-organic frameworks coated stir bar sorptive extraction coupled to high performance liquid chromatography-ultraviolet detector for the determination of estrogens in environmental water samples', Journal of Chromatography A. Elsevier B.V., 1310, pp. 21-30. doi: 10.1016/j.chroma.2013.08.047.

Hussain, C. M. and Kharisov, B. (2016) Advanced Environmental Analysis, Applications of Nanomaterials. The Royal Society of Chemistry.

Iqbal, Z. et al. (2011) 'Rapid CE-UV binding tests of environmentally hazardous compounds with polymer-modified magnetic nanoparticles', Electrophoresis 2011, 32, pp. 2181-2187. doi: 10.1002/elps.201100106.

Ji, Y. et al. (2009) 'Preparation of magnetic molecularly imprinted polymer for rapid determination of bisphenol A in environmental water and milk samples', Anal. Bioanal. Chem., 395, pp. 1125-1133. doi: 10.1007/s00216-009-3020-5.

Jurado-sánchez, B., Ballesteros, E. and Gallego, M. (2009) 'Fullerenes for aromatic and nonaromatic N-nitrosamines discrimination', Journal of Chromatography A, 1216, pp. 1200-1205. doi: 10.1016/j.chroma.2008.12.033.

Karimipour, G. et al. (2012) 'Modification of Gold Nanoparticle Loaded on Activated Carbon with $\operatorname{Bis}(4$-methoxysalicylaldehyde)-1,2-Phenylenediamine as New Sorbent for Enrichment of Some Metal Ions', Biol Trace Elem Res, 145, pp. 109-117. doi: 10.1007/s12011011-9153-3.

Katsumata, H. et al. (2010) 'Preconcentration of atrazine and simazine with multiwalled carbon nanotubes as solid-phase extraction disk', Microchemical Journal. Elsevier B.V., 96(2), pp. 348-351. doi: 10.1016/j.microc.2010.06.005.

Kaur, R. et al. (2014) 'Synthesis and surface engineering of magnetic nanoparticles for environmental cleanup and pesticide residue analysis: A review', J. Sep. Sci. 2014, 37, pp. 1805-1825. doi: $10.1002 / \mathrm{jssc} .201400256$.

Kocot, K. et al. (2013) 'Dispersive micro solid-phase extraction using multiwalled carbon nanotubes combined with portable total-reflection X-ray fluorescence spectrometry for the determination of trace amounts of $\mathrm{Pb}$ and $\mathrm{Cd}$ in water samples', J. Anal. At. Spectrom., 28, pp. 736-742. doi: 10.1039/c3ja50047k.

Kroto, H. W. et al. (1985) 'C60: Buckminsterfullerene', Nature, 318, pp. 162-163.

Lasarte-aragonés, G. et al. (2013) 'Effervescence-assisted carbon nanotubes dispersion for the micro-solid-phase extraction of triazine herbicides from environmental waters', Anal Bioanal Chem, 405, pp. 3269-3277. doi: 10.1007/s00216-013-6718-3.

Leopold, K., Foulkes, M. and Worsfold, P. J. (2009) 'Gold-Coated Silica as a Preconcentration Phase for the Determination of Total Dissolved Mercury in Natural Waters Using Atomic Fluorescence Spectrometry', Anal. Chem., 81, pp. 3421-3428. doi: 10.1039/B820701A.

Li, X. et al. (2014) 'Solid-phase extraction with the metal-organic framework MIL-101(Cr) combined with direct analysis in real time mass spectrometry for the fast analysis of triazine herbicides', J. Sep. Sci., 37, pp. 1489-1495. doi: 10.1002/jssc.201400151.

Lian, Z. and Wang, J. (2016) 'Determination of ciprofloxacin in Jiaozhou Bay using molecularly imprinted solid-phase extraction followed by high-performance liquid 
chromatography with fluorescence detection', Marine Pollution Bulletin. Elsevier Ltd, 111, pp. 411-417. doi: 10.1016/j.marpolbul.2016.07.034.

Liang, M. and Guo, L. (2009) 'Application of Nanomaterials in Environmental Analysis and Monitoring', Journal of Nanoscience and Nanotechnology, 9(4), pp. 2283-2289. doi: 10.1166/jnn.2009.SE22.

Liang, P. and Peng, L. (2010) 'Ionic liquid-modified silica as sorbent for preconcentration of cadmium prior to its determination by flame atomic absorption spectrometry in water samples', Talanta. Elsevier B.V., 81, pp. 673-677. doi: 10.1016/j.talanta.2009.12.056.

Liu, F. (2009) 'Analysis and applications of nanoparticles in the separation sciences: A case of gold nanoparticles', Journal of Chromatography A, 1216, pp. 9034-9047. doi: 10.1016/j.chroma.2009.07.026.

Liu, Q. et al. (2011) 'Graphene and Graphene Oxide Sheets Supported on Silica as Versatile and High-Performance Adsorbents for Solid-Phase Extraction', Angew. Chem. Int. Ed., 50, pp. 5913-5917. doi: 10.1002/anie.201007138.

Lo, S. et al. (2012) 'Gold Nanoparticle-Aluminum Oxide Adsorbent for Efficient Removal of Mercury Species from Natural Waters', Environ. Sci. Technol., 46, pp. 2724-2730. doi: 10.1021/es203678v.

Lolic, A. et al. (2015) 'Assessment of non-steroidal anti-inflammatory and analgesic pharmaceuticals in seawaters of North of Portugal: Occurrence and environmental risk', Science of the Total Environment, 508, pp. 240-250. doi: 10.1016/j.scitotenv.2014.11.097.

López-garcía, I., Rivas, R. E. and Hernández-córdoba, M. (2011) 'Use of carbon nanotubes and electrothermal atomic absorption spectrometry for the speciation of very low amounts of arsenic and antimony in waters', Talanta, 86, pp. 52-57. doi: 10.1016/j.talanta.2011.07.105.

Lucena, R. et al. (2011) 'Potential of nanoparticles in sample preparation', Journal of Chromatography A. Elsevier B.V., 1218, pp. 620-637. doi: 10.1016/j.chroma.2010.10.069.

Luo, X. et al. (2014) 'Graphene nanoplatelets as a highly efficient solid-phase extraction sorbent for determination of phthalate esters in aqueous solution', Talanta. Elsevier, 120, pp. 71-75. doi: 10.1016/j.talanta.2013.11.079.

Ma, J. et al. (2010) 'Determination of 16 polycyclic aromatic hydrocarbons in environmental water samples by solid-phase extraction using multi-walled carbon nanotubes as adsorbent coupled with gas chromatography-mass spectrometry', Journal of Chromatography A. Elsevier B.V., 1217(34), pp. 5462-5469. doi: 10.1016/j.chroma.2010.06.060.

Ma, R. et al. (2016) 'Magnetic porous carbon derived from a metal-organic framework as a magnetic solid-phase extraction adsorbent for the extraction of sex hormones from water and human urine', J. Sep. Sci., 39, pp. 3571-3577. doi: 10.1002/jssc.201600347.

Madadizadeh, M., Taher, M. A. and Ashkenani, H. (2013) 'Determination of ultra-trace amounts of cadmium by ET-AAS after column preconcentration with a new sorbent of modified MWCNTs', Environ Monit Assess, 185, pp. 4097-4105. doi: 10.1007/s10661-0122852-1.

Masoumi, A., Ghaemy, M. and Bakht, A. N. (2014) 'Removal of Metal Ions from Water Using Poly (MMA-co-MA)/Modified-Fe3O4 Magnetic Nanocomposite: Isotherm and Kinetic Study', Ind. Eng. Chem. Res., 53, p. 8188-8197. doi: 10.1021/ie5000906.

Mehdinia, A. et al. (2014) 'Magnetic solid phase extraction using gold immobilized magnetic mesoporous silica nanoparticles coupled with dispersive liquid-liquid microextraction for determination of polycyclic aromatic hydrocarbons', Journal of 
Chromatography A. Elsevier B.V., 1364, pp. 20-27. doi: 10.1016/j.chroma.2014.08.063.

Mehdinia, A., Roohi, F. and Jabbari, A. (2011) 'Rapid magnetic solid phase extraction with in situ derivatization of methylmercury in seawater by $\mathrm{Fe} 3 \mathrm{O} 4 /$ polyaniline nanoparticle', Journal of Chromatography A. Elsevier B.V., 1218(28), pp. 4269-4274. doi: 10.1016/j.chroma.2011.04.070.

Meng, J. et al. (2011) 'Preparation of polypyrrole-coated magnetic particles for micro solidphase extraction of phthalates in water by gas chromatography-mass spectrometry analysis', Journal of Chromatography A. Elsevier B.V., 1218, pp. 1585-1591. doi: 10.1016/j.chroma.2011.01.057.

Menzie, C. A., Potocki, B. B. and Santodonato, J. (1992) 'Exposure to carcinogenic PAHs in the environment', Environ. Sci. Technol., 26(7), pp. 1278-1284.

Nabid, M. R. et al. (2012) 'Preparation and application of poly (2-amino thiophenol)/MWCNTs nanocomposite for adsorption and separation of cadmium and lead ions via solid phase extraction', Journal of Hazardous Materials. Elsevier B.V., 203-204, pp. 93100. doi: 10.1016/j.jhazmat.2011.11.096.

Nilsson, C., Birnbaum, S. and Nilsson, S. (2007) 'Use of nanoparticles in capillary and microchip electrochromatography', Journal of Chromatography A, 1168, pp. 212-224. doi: 10.1016/j.chroma.2007.07.018.

Omidi, F. et al. (2015) 'Solid phase extraction and trace monitoring of cadmium ions in environmental water and food samples based on modified magnetic nanoporous silica', Journal of Magnetism and Magnetic Materials. Elsevier, 395, pp. 213-220. doi: 10.1016/j.jmmm.2015.07.093.

Ozcan, S. G., Satiroglu, N. and Soylak, M. (2010) 'Column solid phase extraction of iron (III), copper (II), manganese (II) and lead (II) ions food and water samples on multi-walled carbon nanotubes', Food and Chemical Toxicology. Elsevier Ltd, 48(8-9), pp. 2401-2406. doi: 10.1016/j.fct.2010.05.078.

Pandey, S. K., Kim, K. and Brown, R. J. C. (2011) 'A review of techniques for the determination of polycyclic aromatic hydrocarbons in air', Trends in Analytical Chemistry. Elsevier Ltd, 30(11), pp. 1716-1739. doi: 10.1016/j.trac.2011.06.017.

Rao, T. N. et al. (2016) 'Pre-concentration of Pesticide Residues in Environmental Water Samples Using Silica Nanoparticles and Identification of Residues By GC-MS Method', Oriental Journal of Chemistry, 32(4), pp. 2221-2230.

Ribeiro, C. et al. (2014) 'New Trends in Sample Preparation Techniques for Environmental Analysis', Critical Reviews in Analytical Chemistry, 44(2), pp. 142-185. doi: 10.1080/10408347.2013.833850.

Sahmetlioglu, E. et al. (2014) 'Polypyrrole/multi-walled carbon nanotube composite for the solid phase extraction of lead (II) in water samples', Talanta. Elsevier, 119, pp. 447-451. doi: 10.1016/j.talanta.2013.11.044.

Sajid, M. et al. (2018) 'Removal of heavy metals and organic pollutants from water using dendritic polymers based adsorbents: A critical review', Separation and Purification Technology, 191, pp. 400-423. doi: 10.1016/j.seppur.2017.09.011.

Savage, N. and Diallo, M. S. (2005) 'Nanomaterials and water purification: Opportunities and challenges', Journal of Nanoparticle Research, 7, pp. 331-342. doi: 10.1007/s11051-0057523-5.

Scragg, A. (2005) 'Environmental monitoring', in Environmental Biotechnology. 2nd edn. 
Oxford University Press.

See, H. H. et al. (2010) 'Determination of triazine herbicides using membrane-protected carbon nanotubes solid phase membrane tip extraction prior to micro-liquid chromatography', Journal of Chromatography A, 1217, pp. 1767-1772. doi: 10.1016/j.chroma.2010.01.053.

Sellergren, B. (1994) 'Direct Drug Determination by Selective Sample Enrichment on an Imprinted Polymer', Anal. Chem., 66(9), pp. 1578-1582.

Sohrabi, M. R. (2014) 'Preconcentration of mercury (II) using a thiol-functionalized metalorganic framework nanocomposite as a sorbent', Microchim Acta, 181, pp. 435-444. doi: 10.1007/s00604-013-1133-1.

Soliman, E. M., Marwani, H. M. and Albishri, H. M. (2013) 'Novel solid-phase extractor based on functionalization of multi-walled carbon nano tubes with 5-aminosalicylic acid for preconcentration of $\mathrm{Pb}$ (II) in water samples prior to determination by ICP-OES', Environ Monit Assess, 185, pp. 10269-10280. doi: 10.1007/s10661-013-3331-z.

Song, X. et al. (2012) 'Determination of 16 polycyclic aromatic hydrocarbons in seawater using molecularly imprinted solid-phase extraction coupled with gas chromatography-mass spectrometry', Talanta. Elsevier, 99, pp. 75-82. doi: 10.1016/j.talanta.2012.04.065.

Soylak, M. and Topalak, Z. (2014) 'Multiwalled carbon nanotube impregnated with tartrazine: Solid phase extractant for Cd (II) and $\mathrm{Pb}$ (II)', Journal of Industrial and Engineering Chemistry. The Korean Society of Industrial and Engineering Chemistry, 20(2), pp. 581-585. doi: 10.1016/j.jiec.2013.05.017.

Soylak, M. and Unsal, Y. E. (2012) 'Determination of Traces of Iron and Lead in Food and Water Samples After Preconcentration on Multiwalled Carbon Nanotubes', Journal of AOAC International, 95(4), pp. 1183-1189. doi: 10.5740/jaoacint.11-168.

Sun, N. et al. (2014) 'A self-assembly pipette tip graphene solid-phase extraction coupled with liquid chromatography for the determination of three sulfonamides in environmental water', Analytica Chimica Acta. Elsevier B.V., 810, pp. 25-31. doi: 10.1016/j.aca.2013.12.013.

Tan, F. et al. (2011) 'Evaluation of a novel microextraction technique for aqueous samples: Porous membrane envelope filled with multiwalled carbon nanotubes coated with molecularly imprinted polymer', J. Sep. Sci., 34, pp. 707-715. doi: 10.1002/jssc.201000791.

Tian, J. et al. (2013) 'Application of nanomaterials in sample preparation', Journal of Chromatography A. Elsevier B.V., 1300, pp. 2-16. doi: 10.1016/j.chroma.2013.04.010.

Tolmacheva, V. V et al. (2016) 'Facile synthesis of magnetic hypercrosslinked polystyrene and its application in the magnetic solid-phase extraction of sulfonamides from water and milk samples before their HPLC determination', Talanta. Elsevier, 152, pp. 203-210. doi: 10.1016/j.talanta.2016.02.010.

UNEP (no date a) All POPs listed in the Stockholm Convention. Available at: http://chm.pops.int/TheConvention/ThePOPs/ListingofPOPs/tabid/2509/Default.aspx (Accessed: 25 February 2019).

UNEP (no date b) MAJOR SOURCES OF TODAY'S POLLUTION. Available at: https://environmentlive.unep.org/media/imgs/pollution/infographics/sources_of_pollution.pdf (Accessed: 25 February 2019).

UNEP (no date c) Persistent organic pollutants (POPs). Available at: https://www.unenvironment.org/explore-topics/chemicals-waste/what-we-do/persistentorganic-pollutants-pops (Accessed: 25 February 2019).

UNEP, Working Group on the Global Metal Flows to the International Resource Panel. van 
der Voet, E.; Salminen, R.; Eckelman, M.; Mudd, G.; Norgate, T.; Hischier, R. (2013) Environmental Risks and Challenges of Anthropogenic Metals Flows and Cycles. Available at: http://orbit.dtu.dk/files/54666484/Environmental_Challenges_Metals_Full_Report.pdf.

UNEP/UNECE (2016) GEO-6 Assessment for the pan-European region. Nairobi, Kenya. Available http://uneplive.unep.org/media/docs/assessments/GEO_6_Assessment_pan_European_region. pdf.

Vunain, E., Mishra, A. K. and Mamba, B. B. (2016) 'Dendrimers, mesoporous silicas and chitosan-based nanosorbents for the removal of heavy-metal ions: A review', International Journal of Biological Macromolecules. Elsevier B.V., 86, pp. 570-586. doi: 10.1016/j.ijbiomac.2016.02.005.

Wang, H. and Campiglia, A. D. (2010) 'Direct determination of benzo[a]pyrene in water samples by a gold nanoparticle-based solid phase extraction method and laser-excited timeresolved Shpol'skii spectrometry', Talanta. Elsevier B.V., 83(1), pp. 233-240. doi: 10.1016/j.talanta.2010.09.013.

Wang, T. et al. (2018) 'Adsorption of agricultural wastewater contaminated with antibiotics, pesticides and toxic metals by functionalized magnetic nanoparticles', Journal of Environmental Chemical Engineering. Elsevier, 6, pp. 6468-6478. doi: 10.1016/j.jece.2018.10.014.

Wang, W. et al. (2013) 'Magnetic microsphere-confined graphene for the extraction of polycyclic aromatic hydrocarbons from environmental water samples coupled with high performance liquid chromatography-fluorescence analysis', Journal of Chromatography A. Elsevier B.V., 1293, pp. 20-27. doi: 10.1016/j.chroma.2013.03.071.

Wang, X. et al. (2017) 'Facile synthesis of phenyl-modified magnetic graphene/ mesoporous silica with hierarchical bridge-pore structure for efficient adsorption of pesticides', Materials Chemistry and Physics. Elsevier B.V, 198, pp. 393-400. doi: 10.1016/j.matchemphys.2016.12.017.

Wang, Y. et al. (2013) 'Preparation of a functionalized magnetic metal-organic framework sorbent for the extraction of lead prior to electrothermal atomic absorption spectrometer analysis', J. Mater. Chem. A, 1, pp. 8782-8789. doi: 10.1039/c3ta11178d.

Wang, Z. et al. (2013) 'Graphene-based solid-phase extraction disk for fast separation and preconcentration of trace polycyclic aromatic hydrocarbons from environmental water samples', J. Sep. Sci., 36, pp. 1834-1842. doi: 10.1002/jssc.201300186.

Wen, Y. et al. (2014) 'Recent advances in solid-phase sorbents for sample preparation prior to chromatographic analysis', Trends in Analytical Chemistry. Elsevier B.V., 59, pp. 26-41. doi: 10.1016/j.trac.2014.03.011.

Wierucka, M. and Biziuk, M. (2014) 'Application of magnetic nanoparticles for magnetic solid-phase extraction in preparing biological, environmental and food samples', Trends in Analytical Chemistry. Elsevier B.V., 59, pp. 50-58. doi: 10.1016/j.trac.2014.04.007.

$\mathrm{Wu}, \mathrm{H}$. et al. (2010) 'Flow injection solid-phase extraction using multi-walled carbon nanotubes packed micro-column for the determination of polycyclic aromatic hydrocarbons in water by gas chromatography-mass spectrometry', Journal of Chromatography A. Elsevier B.V., 1217(17), pp. 2911-2917. doi: 10.1016/j.chroma.2010.02.040.

$\mathrm{Wu}$, X. et al. (2013) 'Graphene-dispersive solid-phase extraction of phthalate acid esters from environmental water', Science of the Total Environment. Elsevier B.V., 444, pp. 224-230. 
doi: 10.1016/j.scitotenv.2012.11.060.

Wu, Z., Lin, J. and Tseng, W. (2012) 'Oligonucleotide-functionalized silver nanoparticle extraction and laser-induced fluorescence for ultrasensitive detection of mercury (II) ion', Biosensors and Bioelectronics. Elsevier B.V., 34(1), pp. 185-190. doi: 10.1016/j.bios.2012.01.041.

WWAP, (United Nations World Water Assessment Programme) (2017) The United Nations world water development report, 2017: Wastewater: the untapped resource.

$\mathrm{Xu}$, L. et al. (2016) 'Recent advances in applications of nanomaterials for sample preparation', Talanta. Elsevier, 146, pp. 714-726. doi: 10.1016/j.talanta.2015.06.036.

Yalçinkaya, Ö. et al. (2012) 'Preconcentration of Aluminum on Nano ZrO2/B2O3 and Its Determination by Flame Atomic Absorption Spectrometry', Spectroscopy Letters, 45, pp. 344351. doi: $10.1080 / 00387010.2012 .666700$.

Yang, F. et al. (2011) 'Magnetic microsphere confined ionic liquid as a novel sorbent for the determination of chlorophenols in environmental water samples by liquid chromatography', J. Environ. Monit., 13, pp. 440-445. doi: 10.1039/c0em00389a.

Yang, W. et al. (2013) 'Molecularly imprinted polymers coated on multi-walled carbon nanotubes through a simple indirect method for the determination of 2,4-dichlorophenoxyacetic acid in environmental water', Applied Surface Science. Elsevier B.V., 284, pp. 692-699. doi: 10.1016/j.apsusc.2013.07.157.

Yin, Y. et al. (2012) 'Dummy molecularly imprinted polymers on silica particles for selective solid-phase extraction of tetrabromobisphenol A from water samples', Journal of Chromatography A. Elsevier B.V., 1220, pp. 7-13. doi: 10.1016/j.chroma.2011.11.065.

$\mathrm{Yu}$, Z. et al. (2010) 'Application of SPE Using Multi-Walled Carbon Nanotubes as Adsorbent and Rapid Resolution LC-MS-MS for the Simultaneous Determination of 11 Triazine Herbicides Residues in River Water', Chromatographia, 72(11), pp. 1073-1081. doi: 10.1365/s10337-010-1769-5.

Zhang, X. et al. (2011) 'A core-shell magnetic mesoporous silica sorbent for organic targets with high extraction performance and anti-interference ability', Chem. Commun., 47, pp. 44544456. doi: 10.1039/c1cc10300h.

Zhang, Z. et al. (2006) 'Applications of nanomaterials in liquid chromatography: Opportunities for separation with high efficiency and selectivity', J. Sep. Sci., 29, pp. 18721878. doi: $10.1002 /$ jssc. 200600154 .

Zhu, H. et al. (2011) 'Preparation of a molecularly imprinted polymer using TMB as a dummy template and its application as SPE sorbent for determination of six PBBs in water and fish samples', Anal. Methods, 3, pp. 393-399. doi: 10.1039/c0ay00479k. 